\title{
The Orderly Liquidation Authority: Fanatical or Familiar? Idealistic or Unrealistic?
}

\section{Citation}

Stephanie Massman, The Orderly Liquidation Authority: Fanatical or Familiar? Idealistic or Unrealistic? (2014).

\section{Permanent link}

http://nrs.harvard.edu/urn-3:HUL.InstRepos:13390873

\section{Terms of Use}

This article was downloaded from Harvard University's DASH repository, and is made available under the terms and conditions applicable to Other Posted Material, as set forth at http:// nrs.harvard.edu/urn-3:HUL.InstRepos:dash.current.terms-of-use\#LAA

\section{Share Your Story}

The Harvard community has made this article openly available.

Please share how this access benefits you. Submit a story.

\section{Accessibility}




\title{
The Orderly Liquidation Authority: Fanatical or Familiar? Idealistic or Unrealistic?
}

\author{
By Stephanie P. Massman
}

The systemic financial crisis of 2008 spurred the failure of numerous financial and non-financial entities. Regulators addressed each of these failures on an ad hoc ex-post basis, granting multiple bailouts in various forms. The refusal to extend these bailouts to one firm, Lehman Brothers, however, caused further panic and contagion throughout the already unstable market as one of the largest financial institutions of the U.S. underwent an extremely lengthy and value-destructive Chapter 11 bankruptcy. Criticism surrounding not only the bailouts, but also the decision to allow Lehman to fail under the Bankruptcy Code, led to the inclusion of the Orderly Liquidation Authority (OLA), a regulatory alternative to bankruptcy for systemically important financial institutions (SIFIs), in the Dodd-Frank Wall Street Reform and Consumer Protection Act. The OLA, although perceived to be a radical departure from traditional bankruptcy, encompasses many familiar resolution principles. Most significant departures from the Bankruptcy Code can be explained by the necessity to ensure the maintenance of financial stability in the national and even global economy in the case of a SIFI failure. By banning future government bailouts as a means to handle a SIFI failure, the OLA also seeks to end the "Too Big To Fail" subsidy and achieve market discipline, such that moral hazard may be minimized. Although the prescribed tactics for effectuating a resolution under the OLA may in fact implicate new moral hazard concerns, many such issues in existence under the old resolution regime have indeed been eliminated. What remains to be seen is the extent to which the agencies will assume their proscribed authority to regulate these SIFIs and the extent to which the market will find their regulations credible. 


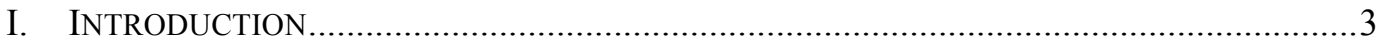

II. COMPARISON OF TITLE II \& THE BANKRUPTCY CODE.............................................

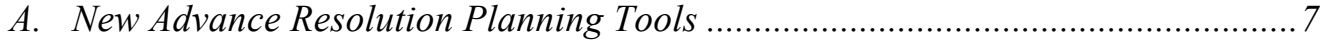

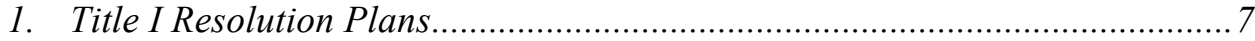

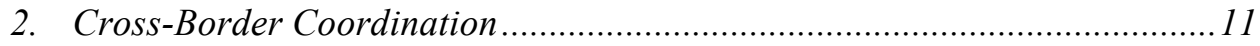

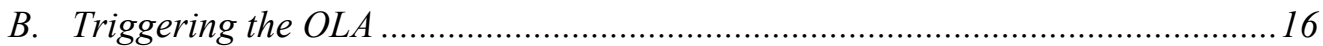

1. "In Default or in Danger of Default"........................................................16

2. "Serious Adverse Effects on Financial Stability" and "No Viable Private

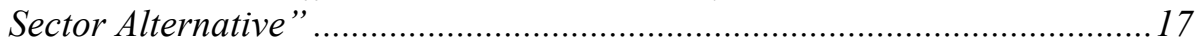

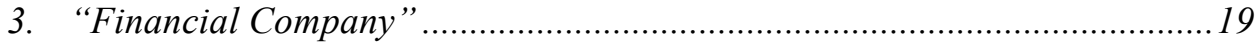

C. Key Divergences of the OLA from Traditional Bankruptcy Law ........................20

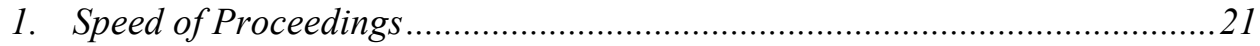

2. Advance Dividends and Distributions to Creditors \& Disparate Treatment of

Similarly Situated Creditors .......................................................................223

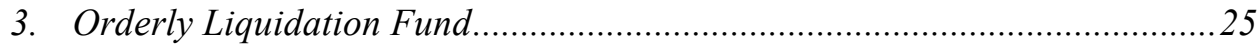

4. Qualified Financial Contract Treatment ...................................................26

5. Single Point of Entry Strategy \& Bridge Financial Companies ....................28

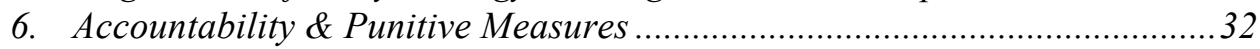

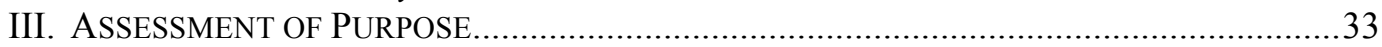

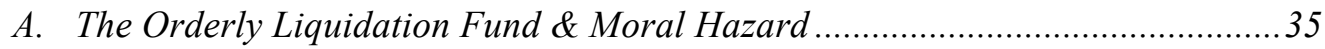

1. The Orderly Liquidation Fund \& "Too Big To Fail”. .....................................36

2. The Orderly Liquidation Fund \& Market Discipline.....................................38

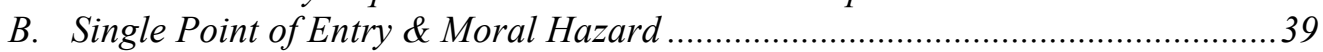

1. Single Point of Entry \& "Too Big To Fail ”................................................40

2. Single Point of Entry \& Market Discipline ................................................40

C. Punitive and Accountability Measures \& Financial Stability..............................41

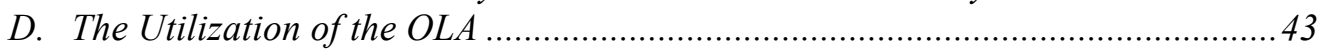

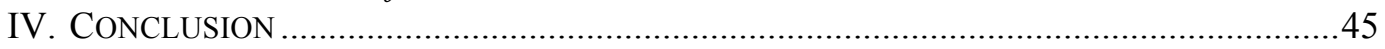




\title{
The Orderly Liquidation Authority: Fanatical or Familiar? Idealistic or Unrealistic?
}

\author{
By Stephanie P. Massman
}

\section{INTRODUCTION}

No one definitive cause has been pinpointed for the 2008 financial crisis; rather, multiple theories have abounded. The one that ultimately influenced the regulatory reform enacted in the wake of the crisis is that a historical government use of bailouts created a market assumption of a "Too Big To Fail" (TBTF) subsidy, which, along with general market discipline erosion, cultivated a pervasive moral hazard problem among all players in the financial industry. As a result, management teams of large financial institutions made poor investment choices and the creditors of those institutions failed to accurately monitor risk. Once various financial institutions began failing in 2008, government agencies claimed they had no true ability or authority to handle the problems, and thus, the solutions they parsed together were created on an ad hoc basis, which only fueled the already widespread uncertainty and panic in the market. Bear Stearns was saved from failure by an acquisition by JPMorgan Chase \& Co. (JPMorgan), facilitated by a $\$ 29$ billion non-recourse loan by the Federal Reserve. The Federal National Mortgage Association (Fannie Mae) and the Federal Home Loan Mortgage Corporation (Freddie Mac) were placed into government-controlled conservatorship and guaranteed access to capital investments of up to $\$ 100$ billion each from the U.S. Treasury. American International Group, Inc. (AIG) was provided with a $\$ 85$ billion line of secured credit from the Federal Reserve, which eventually rose to $\$ 182.3$ billion. Lehman Brothers Holdings Inc. (Lehman) was refused acquisition assistance similar to that received by Bear Stearns and was instead directed by the Federal Reserve to file for Chapter 11 bankruptcy protection under Title 11 of the U.S. Code (Bankruptcy Code).

The disorderly bankruptcy of Lehman caused systemic problems throughout the economy above and beyond those that precipitated its failure in the first place. Exacerbation of the crisis is said to have been caused by two aspects of Lehman's failure: (1) Lehman's interconnectedness within the market, which caused the unwinding of its business positions to bring down others with it, creating substantial direct collateral damage; and (2) regulators' refusal to uphold the TBTF subsidy and issue a bailout to save Lehman from failure, which caused panic and contagion in the market, creating 
substantial indirect collateral damage. Although the extent to which Lehman's bankruptcy actually resulted in any direct collateral damage has been questioned, the contagion effects spurred by the market uncertainty it created are undeniable.

Criticism reverberated throughout both Wall Street and Main Street, from both Democrats and Republicans, after each choice made by regulators throughout the 2008 financial crisis. Bailouts were criticized for taking money from taxpayers, for fueling moral hazard, and for involving government in business activity where it does not belong. The Lehman bankruptcy was critiqued for disrupting both domestic and international markets and for destroying large amounts of value unnecessarily. Overall lack of precrisis industry oversight was disparaged for failure to prevent these issues in the first place. This condemnation culminated in the Dodd-Frank Wall Street Reform and Consumer Protection Act (Dodd-Frank Act), which, inter alia, bans future bailouts and essentially seeks to minimize any ad hoc ex-post involvement of government funds to prevent the failure of another financial company in a future crisis. In place of these, Title I of the Dodd-Frank Act imposes capital and liquidity requirements to minimize risk exante and reduce the likelihood of initial failure. It also requires submission of Resolution Plans_or "living wills"- by certain designated "Systemically Important Financial Institutions" (SIFIs) to demonstrate their non-disruptive resolvability under the Bankruptcy Code. Title II creates a regulatory alternative to bankruptcy-the Orderly Liquidation Authority (OLA) - to wind down failed SIFIs in a way that does not create the systemic risk like that which erupted from Lehman's bankruptcy. Not only does the OLA seek to offer an acceptable alternative to regulators to handle a SIFI that has indeed failed and cannot—-despite its Resolution Plan—be resolved under the Bankruptcy Code, but it also seeks to provide incentives to reduce firm risk ex-ante and thereby also further limit the likelihood of initial failure.

The OLA places a failed SIFI-referred to as a "covered financial company" under Title II once the OLA has been triggered - into a Federal Deposit Insurance Corporation (FDIC) receivership, similar to that used to wind down failed commercial banks under the Federal Deposit Insurance Act (FDIA). As such, the FDIC is responsible under Title II for promulgating rules to identify precisely how a resolution under the OLA will be completed. Thus far, the agency has issued an interim final rule and five final rules to provide a general comprehensive framework for this new authority. The agency also recently closed the comment period on another proposed rule and a notice that outlines 
more specific guidance on the preferred strategy to be used by the FDIC to carry out an orderly liquidation of a covered financial company-the Single Point of Entry (SPOE) strategy. Additionally, the FDIC has established a Systemic Resolution Advisory Committee (SRAC)—comprised of financial market participants; investors; bankruptcy professionals; representatives from the audit, accounting, credit rating, and legal professions; and academic experts - to assist and advise the FDIC on a broad range of issues regarding the resolution of covered financial companies. The SRAC has met four times since its inception in June 2011. Comments published pursuant to the FDIC's rulemaking, minutes available from the SRAC meetings, speeches and testimonials given by members of both the FDIC and the Federal Reserve, and op-eds by various industry pundits offer significant insight into the government, industry, and public perceptions of this new regulatory resolution regime. This paper seeks to consolidate these views to provide a look into the current state of its development.

Specifically, the first half of this paper will look at the substantive provisions of the OLA's resolution mechanisms, identifying those ways in which this new resolution regime is perceived to be similar to or differ from traditional bankruptcy under the Bankruptcy Code. Although many consider the OLA to be a rejection of traditional bankruptcy law for these SIFIs, ${ }^{1}$ as a practical matter, it seems to be that these resolutions will, in fact, look quite similar to those under the Bankruptcy Code in practice. ${ }^{2}$ Although there are some significant, irreconcilable departures from the Bankruptcy Code, the more significant differences between the two resolution regimes can likely be explained as regulatory protections the OLA provides to guarantee access to certain traditional bankruptcy tools that may not be available in unique circumstances surrounding the collapse of a SIFI. ${ }^{3}$ That is, these divergences aim to ensure financial stability of the economy as a whole in the case of a SIFI failure.

\footnotetext{
${ }^{1}$ See e.g., Douglas G. Baird \& Edward R. Morrison, Dodd-Frank For Bankruptcy Lawyers, 19 AM. BANKR. InST. L. ReV. 287, 287 (2011) ("By common account, the new law reflects a repudiation of traditional bankruptcy law when it comes to the collapse of giant corporations that threaten the economy as a whole.") (citing DAVID A. SKEEL, JR., THE NEW FinANCIAL DEAL: UNDERSTANDING THE DODD-FRANK ACT AND ITS (UNINTENDED) CONSEQUENCES 10 (2011)). ${ }^{2} I d$. ("Far from reflecting a rejection of bankruptcy principles, quite the opposite is true ... Moreover, the mechanics of the new receivership process incorporate basic bankruptcy princples.").

${ }^{3} I d$. at 290 ("[The OLA] may not be that different from where we would have been if a new chapter of the Code had been crafted to deal with the problem of systemically important financial companies.").
} 
In the second half of the paper, the focus will shift back to more broadly assess the OLA's potential ability for successful achievement of both its stated goals-(1) the perseveration of financial stability of the market in the case of a SIFI's failure, and (2) the minimization of moral hazard. ${ }^{4}$ Although it is clear that the OLA has the potential to achieve both of these to a greater extent than could the Bankruptcy Code in the case of a SIFI failure, the degree to which it can fully achieve both of these twin goals simultaneously without sacrificing the other may be problematic. The answer to this question of degree seems to turn on both the precise demands each of those goals entails as well as the precise approach the regulators decide to take in the regime's implementation and the certainty the regulators are able provide to the market regarding this resolution regime's future use.

Outside of the scope of this paper, but of importance when considering this topic is the extent to which the systemic financial crisis of 2008 arose, not out of the chaos caused by Lehman's bankruptcy, but rather, out of a common reassessment of mortgagebacked securities causing panic and contagion in the markets, which could not be stopped by any form of orderly resolution of any specific firm. ${ }^{5}$ To the degree that this was the ultimate instigator of the crisis, although the OLA may aid in stemming inflammation of similar future contagion, it is likely not a suitable solution to preventing it or extinguishing it altogether, and it may indeed become overwhelmed and itself fail altogether in the case of too many simultaneous SIFI collapses. ${ }^{6}$

\footnotetext{
${ }^{4}$ Dodd-Frank Wall Street Reform and Consumer Protection Act $§ 204$ (a) [hereinafter Dodd-Frank Act] ("It is the purpose of this title to provide the necessary authority to liquidate failing financial companies that pose a significant risk to the financial stability of the United States in a manner that mitigates such risk and minimizes moral hazard.").

${ }^{5}$ Kenneth E. Scott, $A$ Guide to The Resolution of Failed Financial Institutions: Dodd-Frank Title II and Proposed Chapter 14, in BANKRUPTCY Not BAILOUT: A SPECIAL CHAPTER 14, at VI.A (Kenneth E. Scott \& John B. Taylor eds., 2012), available at http://media.hoover.org/sites/default/files/documents/guide-to-resolution-project-20120302.pdf. ${ }^{6}$ See Fed. Deposit Ins. Corp., Systemic Resolution Advisory Committee Meeting Minutes (Dec. $10,2012)$ at 64 , available at $\mathrm{http}: / / \mathrm{www} . f d i c . g o v / a b o u t / \mathrm{srac} / 2012 / 2012-12-10$ minutes.pdf [hereinafter Dec. 2012 SRAC Meeting] (Member Volcker pointing out that although "significant progress has been made if the failure of an individual SIFI is envisioned, ... the more likely scenario is a systemic problem in which this resolution procedure would have to be applied to multiple failing SIFIs" and the ability of it to handle that capacity is questionable); See also Fed. Deposit Ins. Corp., Systemic Resolution Advisory Committee Meeting Minutes (June 21, 2011) at 15, available at http://www.fdic.gov/about/srac/11JuneMeetingMins.pdf [hereinafter June 2011 SRAC Meeting] (FDIC Chairwoman Bair stressing that "the FDIC's resolution authority by itself cannot address the lack of lending standards, lack of transparency, and mischaracterizations in asset securitizations and collateralized debt obligations, which never should have gone to market in the first place; that there has to be supervisory reforms, including enforcement of higher capital
} 


\section{COMPARISON OF TITLE II \& THE BANKRUPTCY CODE}

\section{A. New Advance Resolution Planning Tools}

Two provisions of the Dodd-Frank Act provide for new advance resolution planning that will improve the resolvability of a SIFI under any resolution regime: (1) the Title I Resolution Plan requirement ${ }^{7}$ and (2) the cross-border resolution coordination directive. ${ }^{8}$ It has been generally acknowledged that planning is essential in order to achieve an efficient and effective orderly resolution of a SIFI, ${ }^{9}$ and a great deal of work by an extraordinary number of parties has already gone into both of these advance resolution planning efforts.

\section{Title I Resolution Plans}

Title I, Section 165(d) of the Dodd-Frank Act requires that certain designated SIFIs prepare Resolution Plans - or "living wills"-to demonstrate how the company would be resolved in a rapid and orderly manner under the Bankruptcy Code in the event of the company's material financial distress or failure. ${ }^{10}$ These plans will improve the resolvability of a company under either resolution regime (1) by providing increased transparency of the firm's organizational structure to those effectuating a resolution and (2) by actually granting to the Federal Reserve and the FDIC the authority to preemptively force a firm's restructuring to improve its resolvability.

Although these plans must specifically illustrate resolution under only the Bankruptcy Code, and not Title II, they have the potential to improve the resolvability of a SIFI under Title II as well by providing the FDIC with a better understanding of each SIFI's structure, complexity, and processes. These plans must include, inter alia, a detailed, "jurisdiction-by-jurisdiction analyses of the actions each would need to take in a resolution, as well as the actions to be taken by host authorities," "11 a "description of the

standards that will provide a more stable base to prevent institutions from having all of this toxicity on their balance sheets going forward; and that there needs to be market discipline to complement the supervisory process for these institutions.").

${ }^{7} I d . \S 165(\mathrm{~d})$

${ }^{8} I d . \S 210(\mathrm{a})(1)(\mathrm{N})$

${ }^{9}$ June 2011 SRAC Meeting, supra note 6, at 9.

${ }^{10}$ Dodd-Frank Act $§ 165(\mathrm{~d})(1)$.

${ }^{11}$ James R. Wigand, Director, \& Richard J. Osterman, Jr., Acting Gen. Council, Office of Complex Financial Institutions, Statement to U.S. H.R. Subcomm. on Oversight and Investigations \& Comm. on Fin. Services: Who Is Too Big Too Fail? Examining the Application of Title I of the Dodd-Frank Act (Apr. 16, 2013), available at 
covered company's corporate governance structure for creating the resolution plan, ... information regarding the overall organization structure of the company, ... an identification of funding and liquidity requirements, ... information concerning the company's management information systems, ... [and] a description of the interconnectedness and interdependencies of the company's various affiliates." ${ }^{12}$ Initial plans had only to assume "baseline" economic conditions, however subsequent submissions may require the companies to take into account "adverse" and "severely adverse" economic conditions. ${ }^{13}$ For example, the assumptions provided to first round filers were that “an idiosyncratic failure occurs; the firm's failure does not significantly disrupt the market because other participants assume parts of the business; the firm has no access to unsecured funding; there is no extraordinary government support; and that all material entities fail." 14

The FDIC's stated goal of these Resolution Plans is to identify "each firm's critical operations and core business lines, map[] out those operations and core business lines to each firm's material legal entities, and identify[] the key obstacles to a rapid and orderly resolution in bankruptcy." 15 Obstacles identified from the first round of filers include "management information systems' limitations on the ability to aggregate data at the legal entity level; uncertainty with respect to international regimes and actions; and liquidity needs and funding mechanisms." ${ }^{.16}$ Other potential obstacles may be "such areas as a firm's internal organizational structure, interconnections of the firm to other systemic financial companies" and "default and termination provisions of certain types of financial contracts." ${ }^{17}$ Interestingly, the FDIC does not seem to have given explicit guidance regarding treatment of the FDIC insured depository institutions (IDIs) under the Resolution Plans. That is, it is unclear whether the SIFIs should assume that the IDI subsidiaries of the SIFIs would be put into a traditional FDIA receivership in tandem with the holding company's Chapter 11 bankruptcy or if the SIFI will be allowed or expected to ensure the IDI subsidiary's continued operations. Moreover, it is significant to note

http://fdic.gov/news/news/speeches/spapr1613.html [hereinafter Wigand \& Osterman (Apr. 2013)].

${ }^{12}$ Fed. Deposit Ins. Corp., Systemic Resolution Advisory Committee Meeting Minutes (Jan. 25, 2012) at 36, available at http://www.fdic.gov/about/srac/2012/2012-01-25 minutes.pdf [hereinafter January 2012 SRAC Meeting].

${ }^{13}$ Wigand \& Osterman (Apr. 2013), supra note 11.

${ }^{14}$ Dec. 2012 SRAC Meeting, supra note 6, at 65.

${ }^{15}$ Wigand \& Osterman (Apr. 2013), supra note 11.

${ }^{16}$ Dec. 2012 SRAC Meeting, supra note 6, at 65.

${ }^{17}$ Wigand \& Osterman (Apr. 2013), supra note 11. 
that these plans are entirely non-binding in the case of a SIFI failure either through traditional bankruptcy or the OLA. ${ }^{18}$

Many, including members of the FDIC, argue that the true usefulness of the Title I resolution plans provision, however, lies not in the actual Resolution Plans themselves, but in the mechanism which this provision provides to allow the Federal Reserve and the FDIC to force a simplification of a firm's business structure to make it truly resolvable. ${ }^{19}$ This forced restructuring may be imposed if the company fails to submit a credible resolution plan, and it may entail (1) "more stringent capital, leverage, or liquidity requirements," (2) "restrictions on the growth, activities, or operations of the company,", or (3) eventually, divestiture requirements. ${ }^{21}$ However, such measures require a joint determination by the Federal Reserve and the FDIC that the company's Resolution Plan is either (a) not credible or (b) would not facilitate an orderly resolution of the company under the Bankruptcy Code, ${ }^{22}$ and neither guidelines nor definitions for these determinations are provided in either the statute or implementing regulations. ${ }^{23}$ Although this lack of clear guidance may be a delimiting aspect to allow the FDIC and the Federal Reserve to exercise their sound expert judgment, ${ }^{24}$ it also creates uncertainty as to how

\footnotetext{
${ }^{18}$ Dodd-Frank Act $\S 165(d)(6)$ ("A resolution plan submitted in accordance with this subsection shall not be binding on a bankruptcy court, a receiver appointed under title II, or any other authority that is authorized or required to resolve the [SIFI].").

${ }^{19}$ See e.g., Jeremiah O. Norton, Member, Board of Directors of the Fed. Deposit Ins. Corp., Remarks to the American Bankers Association: Discussion on the Current State of Resolution Planning (Oct. 21, 2013), available at http://www.fdic.gov/news/news/speeches/spoct2113.html [hereinafter Norton (Oct. 2013)]; Thomas M. Hoenig, Vice Chairman, Fed. Deposit Ins. Corp., Can We End Financial Bailouts?, Remarks to the Boston Economic Club (May 7, 2014), available at http://www.fdic.gov/news/news/speeches/spmay0714.html ("For the market to serve as disciplinarian and for bankruptcy to be a viable means for resolving systemically important financial firms, these largest most complicated firms must become eligible for bankruptcy. Ending bailouts using the tools authorized in Dodd-Frank requires that the Living Will process be vigorously implemented.").

${ }^{20}$ Dodd-Frank Act $§ 165(\mathrm{~d})(5)(\mathrm{A})$

${ }^{21}$ Dodd-Frank Act $\S 165(d)(5)(B)$

${ }^{22}$ Dodd-Frank Act $\$ 165(\mathrm{~d})(4),(5)$

${ }^{23}$ See Norton (Oct. 2013), supra note 19 (pointing out the lack of definition of "credible," the lack of "specificity as to how the Agencies should determine whether a plan is credible or deficient," and the lack of clarity regarding the definition of "orderly resolution"); see also Orderly Liquidation Authority, 12 CFR § 381.2(o) (2013) (defining "rapid and orderly resolution" as "a liquidation or reorganization that can be accomplished within a reasonable period of time and in a manner that substantially mitigates the risk that the failure of the covered financial company would have serious adverse effects on the financial stability of the U.S."). Note that neither "reasonable period of time" nor "substantially mitigates" are defined.

${ }^{24}$ See Jan. 2012 SRAC Meeting, supra note 12, at 38 (comments by member Fisher).
} 
this authority will be exercised or if it will be exercised at all. ${ }^{25}$ Moreover, despite the significant support this approach seems to have from the FDIC, it is clear that this process will be subject to significant politicization that could stifle its efficacy in a manner reminiscent of regulators' experience with the Volcker Rule and Section 5(e) of the Bank Holding Company Act, which grants regulators the authority to separate problem affiliates to prevent them from endangering a commercial bank but which has never been used. $^{26}$

If, indeed, the FDIC and the Federal Reserve decline to exercise this ex-ante restructuring authority, some argue that increased public disclosure of these plans would have the effect of enhancing market discipline ${ }^{27}$ such that the companies would be under pressure to reorganize themselves. ${ }^{28}$ Such public disclosure could come in the form of improvement of the public portions of the Resolution Plans-as those thus far disseminated have been highly criticized as uninformative ${ }^{29}$ - or in the form of public

\footnotetext{
${ }^{25}$ See Norton (Oct. 2013), supra note 19 (commenting that policymakers could water down the effectiveness of living wills by taking a "more incremental approach by arguing that because terms like 'credible' and 'orderly' are hard to define" or by "view[ing] that orderly resolution of [SIFIs] under traditional bankruptcy law is improbable given recent experiences in 2008 and therefore would not put the considerable weight of their authorities, efforts, and resources behind the process"). ${ }^{26}$ See Hoenig, supra note 19.

${ }^{27}$ See e.g., The Credit Roundtable Comment Letter to the Fed. Deposit Ins. Corp. Notice regarding Resolution of Systemically Important Financial Institutions: The Single Point of Entry Strategy, 78 Fed. Reg. 76614, Feb. 14, 2014, at 2 [hereinafter Credit Roundtable Comment on SPOE Notice].

${ }^{28}$ See Systemic Risk Council Comment Letter to the Fed. Deposit Ins. Corp. Notice regarding Resolution of Systemically Important Financial Institutions: The Single Point of Entry Strategy, 78 Fed. Reg. 76614, Feb. 18, 2014, at 5 [hereinafter SRC Comment on SPOE Notice]; Letter from Systemic Risk Council to Board of Governors of the Fed. Reserve \& Fed. Deposit Ins. Corp. (Dec. 2, 2013), available at http://www.systemicriskcouncil.org/wp-content/uploads/2013/12/SRCletter-to-Fed-and-FDIC-re-Living-Wills-12-02-13.pdf (calling for increased disclosure and credibility of the public portions of $\S 165(\mathrm{~d})$ Resolution Plans). See also Fed. Deposit Ins. Corp., Systemic Resolution Advisory Committee Meeting Transcript (Dec. 11, 2013) [hereinafter Dec. 2013 SRAC Meeting] (Member Herring pointed out that while public market discipline can and should be a goal of the public portions of the living wills, more useful guidance regarding the organizations' structures must be provided).

${ }^{29}$ See SRC Comment on SPOE Notice, supra note 28, at 5; Credit Roundtable Comment on SPOE Notice, supra note 27, at 2. See also Dec. 2013 SRAC Meeting, supra note 28 (Member Herring noting that there was no standardized reporting, terminology, or interpretation of "material entity" among the public portions of the living wills and that data from the SEC and Bankscope does not align with that in the living wills. "At the end of the day, you really knew little more about the structure of the firm, or you knew nothing more about the structure of the firm than you would have known if you had taken all the public documents and tried to reconcile them.").
} 
releases of the findings of the FDIC and the Federal Reserve regarding the credibility of the living wills. ${ }^{30}$

Thus far, three tiers of eligible companies have filed their plans. These include bank holding companies with total consolidated assets of $\$ 50$ billion or more, ${ }^{31}$ nonbank financial companies that the Financial Stability Oversight Council (FSOC) has designated for supervision by the Federal Reserve, ${ }^{32}$ and IDIs with assets over $\$ 50$ billion. ${ }^{33}$ Although some have voiced positivity regarding the credibility and usefulness of these plans, ${ }^{34}$ many continue to question their meaningfulness and some go so far as to declare them entirely lacking in credibility. ${ }^{35}$ While some believe that reliance upon the OLA to handle a SIFI failure is a satisfactory and appropriate solution, ${ }^{36}$ others sharply critique this view as sapping incentives for market discipline and perpetuating systemic risk. These critics call for regulatory action to take full advantage of the authority granted under this provision of the Dodd-Frank Act to force the divestiture of certain assets or force a reorganization of the company to make it truly resolvable under the Bankruptcy Code. $^{37}$

\section{Cross-Border Coordination}

The Dodd-Frank Act includes in the OLA a mandate to the FDIC to "coordinate, to the maximum extent possible, with the appropriate foreign financial authorities regarding the orderly liquidation of any covered financial company" with cross-border operations. ${ }^{38}$ The achievement of this directive to establish effective cross-border coordination is widely acknowledged to be essential to the resolution of a global SIFI (G-SIFI). ${ }^{39}$ Indeed,

\footnotetext{
${ }^{30}$ See SRC Comment on SPOE Notice, supra note 28, at 5.

${ }^{31}$ Resolution Plans, 12 C.F.R. § 381.2(f)(ii), (iii) (2013).

${ }^{32} I d . \S 381.2(\mathrm{f})(\mathrm{i})$.

${ }^{33}$ Resolution and Receivership Rules, 12 C.F.R. $§ 360.10$ (2013).

${ }^{34}$ See Dec. 2013 SRAC Meeting, supra note 28 (Member Cohen commenting, "Having had an opportunity to be involved in several of these plans, I can assure, at least the ones I was involved with, the Boards were deeply involved. . [T]hey are intensely focused on liquidity, and they are intensely focused on making sure they don't bring others down with them.").

${ }^{35}$ See Johnson, Big Banks, supra note 73 ("living wills cannot be credible because the big banks are incredibly complex, with cross-border operations and a web of interlocking activities").

${ }^{36}$ See Hoenig, supra note 19 (citing Bipartisan Policy Center, Too Big to FaIL: The Path to A SOLUTION (May 14, 2013).

${ }^{37}$ See id. ("The Fed and the F.D.I.C. must require remedial action, meaning that something about the size, structure, and strategy of the megabanks must change .... Section 165 is potentially valuable, but only if the relevant officials recognize this reality and act on it.").

${ }_{38}^{38}$ Dodd-Frank Act $\S 210(\mathrm{a})(1)(\mathrm{N})$.

${ }^{39}$ See e.g., Charles Randell, The FSB's "Key Attributes": The Road to Cross-Border Resolution of Financial Institutions 6 (Dec. 6, 2012) (discussion draft) ("A complete solution to the problem of
} 
such coordination - and specifically, assurances of such coordination-is one of the most significant concerns addressed in the comment letters to the FDIC's SPOE Notice. This coordination, while being established under the umbrella of the OLA, is meant to provide assurances to all relevant jurisdictions in the case of a G-SIFI failure abroad, such that it should be extraordinarily useful even upon a G-SIFI's failure through traditional bankruptcy. Prior to Lehman's failure, there was no such coordination; in fact, it was not even "the subject of signification international attention" at all. ${ }^{40}$ It is because of this lack of coordination that led foreign regulators to panic when Lehman did fail, causing over 100 separate insolvency proceedings across jurisdictions, ${ }^{41}$ ring-fencing, and liquidity crises among the company's internationally sprawled subsidiaries. According to FDIC Chairman Martin Gruenberg, there has been "a sea [of] change since 2008 in terms of international recognition of the importance of these cross-border relationships and the need for cooperation." 42 This topic has now become "a subject of intense international attention" on both the multilateral level by the Basel Committee and the Financial Stability Board (FSB), as well as the bilateral level between individual national and regional regulators. ${ }^{43}$

Most significantly on the multilateral level is the FSB's publication of its Key Attributes of Effective Resolution for Financial Institutions. These Key Attributes, which extensively parallel the Bankruptcy Code and OLA, ${ }^{44}$ seek to establish an international standard for resolution regimes and to create a framework for international cooperation in the resolution of a G-SIFI. While not formally binding, the Key Attributes establish a program of country and thematic peer reviews of member jurisdictions to incentivize compliance. Notably, the EU has recently come substantially further into compliance with the Key Attributes, and therefore into further alignment with the U.S. resolution regimes, through the announcement of their Bank Recovery and Resolution Directive, a financial regulatory framework for winding down failed banks that applies to all 28

the resolution of G-SIFIs therefore needs to produce a suite of resolution tools, but also an answer to the problem of cross-border cooperation.").

${ }^{40}$ See Martin J. Gruenberg, Chairman, Fed. Deposit Ins. Corp., Remarks to the Annual Wash. Conf. of the Inst. of Int'l Bankers (Mar. 4, 2013), available at http://fdic.gov/news/news/speechs/spmar0413.html [hereinafter Gruenberg (Mar. 2013)].

${ }^{41}$ See Harvey R. Miller \& Maurice Horwitz, A Better Solution Is Needed for Failed Financial Giants, N.Y. Times (Oct. 9, 2012) http://dealbook.nytimes.com/2012/10/09/a-better-solution-isneeded-for-failed-financial-giants/.

${ }^{42}$ Dec. 2012 SRAC Meeting, supra note 6, at 43.

${ }^{43}$ See Gruenberg (Mar. 2013), supra note 40.

${ }^{44}$ E.g., use of resolution plans, "no worse off than in liquidation" requirements, bail-in requirements. 
Member States. ${ }^{45}$ It remains to be seen, however, how this directive will be implemented into statutes in the individual Member States, an issue that could crucially determine its effectiveness. Moreover, this directive applies only to banks and not to nonbank financial institutions, the category under which Lehman would have fallen prior to its failure. The establishment of a framework for the resolution of such nonbank financial institutions has yet to proceed past a consultation, which was occurred in $2012 .^{46}$

In addition to contributing to the development of multilateral coordination initiatives to bring more countries closer towards the same resolution standards, the FDIC has also sought to establish more specific bilateral agreements with certain key jurisdictions. These efforts seek to "identify impediments to orderly resolution that are unique to specific jurisdictions and discuss how to mitigate such impediments through rule changes or bilateral cooperation," "examine possible resolution strategies and practical issues related to implementation of such strategies with respect to particular jurisdictions," and establish information sharing coordination. ${ }^{47}$ In December of 2012, the FDIC published a joint paper with the Bank of England outlining how the SPOE strategy would be an effective way to resolve a cross-border financial institution without disrupting operations in subsidiaries in either jurisdiction. ${ }^{48}$ As is evident by this paper and by the U.K.'s recent acceptance of the EU Bank Recovery and Resolution Directive, the U.K. is increasingly adopting U.S. methods of resolution such that a case such as Lehman's could be handled more efficiently in the future. Additionally, significant bilateral work has been done with Switzerland, ${ }^{49}$ Japan, ${ }^{50}$ and the European Commission (EC) $;{ }^{51}$ and the FDIC has engaged

\footnotetext{
${ }^{45}$ Press Release, European Commission, Comm'r Barnier welcomes trilogue agreement on the framework for bank recovery and resolution (Dec. 12, 2013) http://europa.eu/rapid/pressrelease MEMO-13-1140 en.htm.

${ }^{46}$ European Commission, Consultation on a Possible Recovery and Resolution Framework for Financial Institutions Other Thank Banks (2012) http://ec.europa.eu/internal market/consultations/2012/nonbanks/consultation-document en.pdf.

${ }^{47}$ Martin J. Gruenberg, Acting Chairman, Fed. Deposit Ins. Corp., Statement to U.S. S. Comm. on Banking, Housing, and Urban Affairs: Implementing Wall Street Reform: Enhancing Bank Supervision and Reducing Systemic Risk (June 6, 2012), available at http://www.fdic.gov/news/news/speeches/chairman/spjun0612.html.

${ }^{48}$ Fed. DePosit Ins. CoRP. \& BANK OF ENG., JOINT PAPER, RESOlving Globally ACtive, SYSTEMICALly IMPORTANT, FinANCIAL InSTITUTIONS (Dec. 10, 2012), available at http://www.fdic.gov/about/srac/2012/gsifi.pdf.

${ }^{49}$ James R. Wigand, Director, Office of Complex Financial Institutions, Statement to the U.S. S. Subcomm. on National Security and International Trade and Finance: Improving Cross Border Resolution to Better Protect Taxpayers and The Economy (May 15, 2013), available at http://www.fdic.gov/news/news/speeches/spmay1513 2.html [hereinafter Wigand (May 2013)] (indicating that both bilateral and trilateral - including the U.K.- -work has been done with Switzerland, home to two G-SIFIs with significant operations in the U.S.).
} 
in active dialogues to conclude Memorandums of Understanding (MOUs) with at least 26 jurisdictions. $^{52}$

Although many continue to question the efficacy of these efforts and doubt the ability of regulators to effectuate any meaningful solution to the cross-border problem, ${ }^{53}$ a heatmapping exercise undertaken by the FDIC suggests that "international cooperation is far more closely within reach than ... has been recognized." The findings of that exercise demonstrated "that, while a systemically important financial institution may have thousands of subsidiaries and a large global footprint, an international resolution strategy would actually be dealing with a fairly manageable list of key foreign jurisdictions to prioritize and small number of legal entities that are very powerful drivers in the operations of the institution's global footprint." ${ }^{, 54}$ For example, over $90 \%$ of the total reported foreign activity for the top seven U.S. SIFIs is located in just three foreign jurisdictions. ${ }^{55}$ Moreover, over $85 \%$ of the total reported foreign activity for those top seven U.S. SIFIs comes from just one to seven legal entities. ${ }^{56}$ Despite these findings, it remains undeniable that Lehman was comprised of about 8,000 legal entities in 40 countries, and its failure spurred over 100 separate insolvency proceedings around the world. $^{57}$

In addition to mere coordination and information sharing agreements with foreign regulators, the FDIC is also contemplating ex-ante subsidiarization requirements, which would require SIFIs to conduct their foreign operations through subsidiaries rather than

\footnotetext{
${ }^{50} I d$. (indicating that the FDIC had meetings in March 2013 with the Deposit Insurance Corporation of Japan "to discuss the FDIC's resolution strategy under the OLA and the treatment of qualified financial contracts under the Dodd-Frank Act" and the Japan Financial Services Agency "to discuss our respective resolution regimes," including the "current legislative proposal to amend Japan's existing resolution regime to enhance authorities ability to resolve SIFIs.").

${ }^{51}$ Gruenberg (Mar. 2013), supra note 40 (indicating that the FDIC meets twice a year with a working group from the EC to discuss issues of resolution and deposit insurance, including "the EC's proposed directive on bank recovery and resolution; deposit guarantee regimes; the FDIC's work on planning for SIFI resolutions; and future initiatives that might be undertaken related to cross-border cooperation.").

${ }_{52}^{5}$ Dec. 2012 SRAC Meeting, supra note 6, at 56.

${ }^{53}$ See Miller \& Horwitz, supra note 41 (arguing that the OLA does not adequately address crossborder issues).

${ }^{54}$ Jan. 2012 SRAC Meeting, supra note 12, at 40.

${ }^{55}$ Dec. 2012 SRAC Meeting, supra note 6, at 55.

${ }^{56} \mathrm{Id}$. at 55 .

${ }^{57}$ Miller \& Horwitz, supra note 41.
} 
through branches. ${ }^{58}$ This proposal has been met with significant contention from both sides of the debate. Those in favor of it believe that such a subsidiarization approach would produce increased operational efficiencies, increased transparency for investors, and increased resolvability under either the Bankruptcy Code or the OLA. ${ }^{59}$ On the other hand, many believe forcing such subsidiarization upon a company would be a costly and inefficient regulation, providing little or no benefit. ${ }^{60}$ Moreover, some believe that, absent adequate prepositioned intracompany lines of credit, a subsidiarization structure could pose a threat to liquidity transfers upon commencement of a resolution proceeding, whereas access by the subsidiary to the holding company's liquidity is more assured in a branch structure. ${ }^{61}$

While the efforts that have been made by the FDIC in the cross-border coordination arena have established a significant "foundation that provides a basis for regulators to share information and be engaged with each other," 62 as of yet none of the international efforts have included any binding agreements. It is clear that industry and public participants will not be assuaged by the FDIC's coordination efforts until they result in something more binding than mere MOUs. Of significant uncertainty is not only whether foreign regulators would be willing to recognize a resolution under the OLA or Bankruptcy Code in the U.S., but whether the FDIC would be willing to recognize a resolution under a foreign regulator's oversight. While the EU's recent Bank Recovery and Resolution Directive does recognize such a commitment to such recognition, the FDIC does not seem to have made clear a parallel one. ${ }^{63}$ Moreover, Vice Chairman of the FDIC Thomas Hoenig has recognized that as matters currently stand, the failure of a GSIFI likely would spark international ring fencing and multiple resolution proceedings, just as Lehman's did. ${ }^{64}$ So although the current status quo may be an improvement from

\footnotetext{
${ }^{58}$ Notice regarding Resolution of Systemically Important Financial Institutions: The Single Point of Entry Strategy, 78 Fed. Reg. 76,614, 76,623-24 (Dec. 18, 2013) [hereinafter SPOE Notice].

${ }^{59}$ See SRC Comment on SPOE Notice, supra note 28, at 4.

${ }^{60} \mathrm{See}$ The Institute of International Bankers Comment Letter to the Fed. Deposit Ins. Corp. Notice regarding Resolution of Systemically Important Financial Institutions: The Single Point of Entry Strategy, 78 Fed. Reg. 76,614, Feb. 18, 2014, at 4 [hereinafter IIB Comment on SPOE Notice].

${ }^{61}$ See Credit Roundtable Comment on SPOE Notice, supra note 27, at 4.

${ }^{62}$ Jan. 2012 SRAC Meeting, supra note 12, at 42.

${ }^{63}$ See The Institute of International Finance Comment Letter to the Fed. Deposit Ins. Corp. Notice regarding Resolution of Systemically Important Financial Institutions: The Single Point of Entry Strategy, 78 Fed. Reg. 76,614, Feb. 18, 2014, at 3 [hereinafter IIF Comment on SPOE Notice].

${ }^{64}$ Hoenig, supra note 19 (“. . . despite improved and on-going efforts at international cooperation, there are no international bankruptcy laws sufficient to sort out cross-border creditor rights and no mechanism to assure the reliability of the enormous cross-border flow of funds of just one of these
} 
the state of information sharing in resolution regimes prior to the crisis, it is clear that a substantial amount of work remains to be done.

\section{B. Triggering the OLA}

A resolution of a SIFI under Title II of the Dodd-Frank Act, utilizing the OLA and appointing the FDIC as receiver of a failed financial company, is triggered following a series of rather complicated steps. It first requires a recommendation to the Secretary of the Treasury by the FDIC (Securities and Exchange Commission for brokers and dealers and Federal Insurance Office for insurance companies) and the Federal Reserve. The Secretary of the Treasury in consultation with the President must then determine, inter alia, that: (1) the financial company is "in default or in danger of default;" (2) its failure under the Bankruptcy Code "would have serious adverse effects on financial stability in the United States;" (3) "no viable private sector alternative is available to prevent the default;" and (4) the company satisfies a rather convoluted definition of a "financial company." ${ }^{65}$ These rather imprecise criteria determine the circumstances that may lead to the resolution of a SIFI under the OLA rather than under the Bankruptcy Code.

\section{1. "In Default or in Danger of Default"}

The determination regarding whether a financial company is "in default or in danger of default" is relatively straightforward. It is to be based upon a finding that: (1) a case has been or is likely to be filed under the Bankruptcy Code; (2) the financial company has incurred or is likely to incur losses that will deplete all or substantially all of its capital; (3) the liabilities of the financial company exceed or are likely to soon exceed its assets; or (4) the financial company cannot or soon will not be able to pay its obligations as they become due in the normal course of business. ${ }^{66}$ Although this determination is somewhat more discretionary, it is similar enough to that required for the commencement of an involuntary case under the Bankruptcy Code,${ }^{67}$ such that a failing company should not truly be surprised to lose control in an involuntary bankruptcy proceeding or in a Title II

firms. "Ring fencing" assets will be the norm rather than the exception. Under such circumstances, it would be foolish to ignore the fact that countries will protect their domestic creditors and stop outflows of funds when crisis threatens.").

${ }^{65}$ Dodd-Frank Act $\S 203$ (b) (listing factors necessary for receivership).

${ }^{66} I d$. $\S 203(\mathrm{c})(4)$ (defining circumstances to be considered "in default or in danger of default").

${ }^{67} 11$ U.S.C. $§ 303(\mathrm{~h})$ (2006) (ordering relief in involuntary case against debtor only if (1) "the debtor is generally not paying such debtor's debts as such debts become due" or (2) a custodian had been appointed or took possession within 120 days of the date of the filing of the petition). 
receivership. ${ }^{68}$ Despite this, several voices from the industry have called for more clarity surrounding the determination of "in danger of default," ${ }^{, 69}$ pointing out that it is not necessarily obvious that a company may be nearing the breaking point, as was the case with Lehman. ${ }^{70}$ Whether regulators would have the ability and the access to inside information necessary to make such a determination when industry professionals cannot is also questionable.

\section{2. "Serious Adverse Effects on Financial Stability" and "No Viable Private Sector Alternative"}

The determinations that a resolution under the Bankruptcy Code would have "serious adverse effects on the financial stability of the United States" and that "no viable private sector alternative is available to prevent the default" are somewhat more ambiguous. The FDIC has repeatedly emphasized the position that traditional bankruptcy is the preferred method of resolution for any company. ${ }^{71}$ However, despite some argument that the Bankruptcy Code can, indeed, effectively handle large corporate resolutions, ${ }^{72}$ the more universally acknowledged point of view is that the Code simply cannot be used successfully to resolve a SIFI in any case, either because there is something inherently different about financial companies that requires an alternative resolution process different from bankruptcy ${ }^{73}$ or because these specific firms are simply too large to be resolved in bankruptcy without causing collateral failures due to interconnectedness or

\footnotetext{
${ }^{68}$ Baird \& Morrison, supra note 1, at 292.

${ }^{69}$ See e.g., Credit Roundtable Comment on SPOE Notice, supra note 27, at 3; Occupy the SEC Comment Letter to the Fed. Deposit Ins. Corp. Notice regarding Resolution of Systemically Important Financial Institutions: The Single Point of Entry Strategy, 78 Fed. Reg. 76614, Mar. 18, 2014, at 2 [hereinafter Occupy the SEC Comment on SPOE Notice].

${ }^{70}$ See Occupy the SEC Comment on SPOE Notice, supra note 69, at 2.

${ }^{71}$ See e.g., Martin J. Gruenberg, Acting Chairman, Fed. Deposit Ins. Corp., Remarks to American Banker Regulatory Symposium (Sept. 14, 2012), available at http://www.fdic.gov/news/news/speeches/chairman/spsep1412.html [hereinafter Gruenberg (Sept. 2012)] ("[U]nder Dodd-Frank, bankruptcy is the option of first recourse... Only in extraordinary circumstances in which an orderly resolution could not be conducted under the bankruptcy code would a Title II orderly liquidation be considered. Title II should not be viewed as a replacement for bankruptcy, but as a last resort to allow the firm to fail without broad systemic disruption.").

${ }^{72}$ See e.g., id. at 292 ("The success of chapter 11 in handling the collapse of very large corporations (such as Enron, General Motors, and Conesco) suggests that [the threshold for determining that the use of the Bankruptcy Code 'would have serious adverse effects on the financial stability of the United States'] is a high one.") .

${ }^{73}$ Dec. 2013 SRAC Meeting, supra note 28 (Member Cohen commenting, "There seems to be a widespread assumption that Title II is an anomaly, that it is radically different than anything that has been before. And rather than that, I think the opposite conclusion is correct; that Title II is just a recognition of what we have recognized for scores of years which is that you resolve financial institutions differently than other corporations.").
} 
contagion. ${ }^{74}$ On the other hand, it is not even entirely clear whether Lehman's bankruptcy caused what would be categorized as "serious adverse effects on the financial stability of the United States. ${ }^{, 75}$ Further complicating the matter is that some people are now calling for changes to the Bankruptcy Code, which could significantly change the conditions that call for use of the OLA instead of traditional bankruptcy. ${ }^{76}$ Although this is not yet an issue, if changes to the Bankruptcy Code are enacted, the analysis under this prong of the OLA trigger may be significantly altered.

What would constitute an acceptable "viable private sector alternative" is also unclear. While it could be something of the sort that aided Long Term Capital Management (LTCM), Bear Stearns, or Merrill Lynch, each of these "private sector alternatives to default" raises questionable results. First of all, the LTCM and Bear Stearns deals were significantly influenced by (or, in the case of Bear Stearns, partially funded by) government regulators, and thus not entirely "privately" accomplished. Additionally, it is questionable whether the LTCM workout would even be possible given the existence of the OLA. That is, the availability of the OLA may make private parties less inclined to even come to the negotiating table to aid a failing financing company if they believe that the FDIC will simply be appointed to handle the company's resolution. ${ }^{77}$ Moreover, the Bear Stearns and Merrill Lynch acquisitions by JPMorgan and Bank of America, respectively, raise questions regarding the ever-expanding size of these financial companies and their true resolvability under the Bankruptcy Code as required

\footnotetext{
${ }^{74}$ See e.g., Simon Johnson, Big Banks and the Failure of Bankruptcy, N.Y. Times (Dec. 19, 2013) http://economix.blogs.nytimes.com/2013/12/19/big-banks-and-the-failure-of-bankruptcy/ [hereinafter Johnson, Big Banks] ("[A]s matters currently stand, bankruptcy for a big financial company would imply chaotic disaster for world markets (as happened after Lehman Brothers failed) ... Bankruptcy cannot work for big banks at their current scale and level of complexity. It is not a viable option under current law.").

${ }^{75}$ Compare Fed. Deposit Ins. Corp., The Orderly Liquidation of Lehman Brothers Holdings Inc. under the Dodd-Frank Act, 5 FDIC Quarterly 31, 31 (2011), available at http://www.fdic.gov/bank/analytical/quarterly/2011 vol5 2/FDIC QuarterlyVo15No2 entire v4.pdf [hereinafter FDIC Lehman Report] ("The disorderly and costly nature of the [Lehman] bankruptcy - the largest... bankruptcy in U.S. history - contributed to the massive financial disruption of late 2008") with HAL S. SCOTT, INTERCONNECTEDNESS AND CONTAGION 3 (2012), available at http://www.capmktsreg.org/pdfs/2012.11.20 Interconnectedness and Contagion.pdf ("Despite the complexity of the bankruptcy process, evidence suggests that direct exposure of counterparties to Lehman entities that filed in the United States was not destabilizing in the immediate aftermath of Lehman's failure.").

${ }^{76}$ See Thomas H. Jackson, Bankruptcy Code Chapter 14: A Proposal, in BANKRUPTCY NoT BAilout: A SPECIAL ChaPTER (Kenneth E. Scott \& John B. Taylor eds., 2012), available at http://media.hoover.org/sites/default/files/documents/Bankruptcy-Code-Chapter-14-Proposal20120228.pdf.

${ }^{77}$ Baird \& Morrison, supra note 1, at 293.
} 
under Title I of the Dodd-Frank Act. Ultimately, despite the FDIC's insistence that the OLA will be used only in "extraordinary circumstances," 78 it appears to be the consensus that any SIFI failure would be indeed be extraordinary such that neither traditional bankruptcy nor a private market resolution could effectively handle the situation.

\section{3. "Financial Company"}

Lastly, the determination of whether a SIFI satisfies the definition of a "financial company" set forth in Title II has the potential to create significant uncertainty. This determination is made wholly apart from that made under Title I to subject companies to the enhanced supervision and prudential standards of Section 165, including the requirement of the creation of a Resolution Plan. Those subject to Title I, Section 165 are (1) "nonbank financial companies supervised by the Board of Governors" and (2) "bank holding companies with total consolidated assets equal to or greater than $\$ 50,000,000,000 .{ }^{\prime 79}$ On the other hand, the companies qualifying for resolution under Title II due to their status as "financial compan[ies]" are: (1) "bank holding company[ies];" (2) "nonbank financial compan[ies] supervised by the Board of Governors;" (3) "company[ies] that [are] predominantly engaged in activities that... are financial in nature or incidental thereto;" and (4) subsidiaries of those companies that are predominantly engaged in financial activities. ${ }^{80}$ Thus, there are a significant number of institutions that may be eligible for resolution under Title II, but may not be subject to exante enhanced supervision and prudential standards under Title I and may not be required to submit a Resolution Plan. These institutions fall into two different categories: (1) those that are eligible for Title I supervision but whom the FSOC has deemed do not "pose a threat to the financial stability of the United States" ${ }^{\prime 81}$; and (2) those that are not eligible for Title I supervision at all—including (i) bank holding companies with assets under $\$ 50$ billion; and (ii) companies and subsidiaries who are "financial companies" as defined under Title II but not Title I. ${ }^{82}$

\footnotetext{
${ }_{78}^{78}$ See Gruenberg (Sept. 2012), supra note 71.

${ }^{79}$ Dodd-Frank Act $\S 165(a)(1)$.

${ }^{80} I d$. $\S 201(\mathrm{a})(11)$.

${ }^{81} I d . \S 115(\mathrm{a})(1)$.

${ }^{82}$ Compare Id. § 201(a)(11)(B)(iii) (Title II's definition of "financial companies" includes those who are "predominantly engaged in activities that... are financial in nature or incidental thereto") with id. § 201(a)(4)(B)(ii) (Title I's definition of "U.S. nonbank financial companies" includes those who are "predominantly engaged in financial activities").
} 
Although administrative flexibility is likely useful in making the decision regarding whether or not to put a company into an OLA receivership, putting a SIFI and its creditors on notice that it may be eligible for resolution under the OLA by also subjecting it to Title I supervision would likely be very beneficial. Moreover, the FDIC and the Federal Reserve could largely remedy the uncertainty caused by the definitional inconsistencies through clearer rulemaking, although they have currently maintained those inconsistencies in their existing rules regarding these definitions. ${ }^{83}$ Thus, there remains some significant work to be done to bring Title I and Title II into alignment and to adequately put SIFIs on notice of their OLA resolution eligibility. Whether or not the FDIC and the Federal Reserve can attain such coordination may be indicative of the potential for future agency coordination, which will be essential to a successful resolution of a SIFI under the OLA.

\section{Key Divergences of the OLA from Traditional Bankruptcy Law}

Although the OLA may at first appear to be a radical departure from traditional bankruptcy law, as a practical matter, resolutions under this new regime will likely look quite similar to those under the Bankruptcy Code. For example, both regimes include the fundamentals of bankruptcy: the automatic stay, ${ }^{84}$ creditor priority, ${ }^{85}$ the "no worse off than in liquidation" requirement, ${ }^{86}$ avoidance of preferential and fraudulent transfers, ${ }^{87}$ contract assumption or rejection power, ${ }^{88}$ etc. In fact, Title II includes a specific directive to the FDIC to harmonize the OLA, to the extent possible, with traditional bankruptcy law. ${ }^{89}$ And although there are certain key divergences of the OLA from traditional bankruptcy law, to a great extent, many of these new tools available under the OLA are merely regulatory protections meant to guarantee access to certain "creative" bankruptcy tools that are currently in practice under the Bankruptcy Code but which may not be

\footnotetext{
${ }^{83}$ Compare Definition of "Predominantly Engaged in Activities That Are Financial in Nature or Incidental Thereto," 78 Fed. Reg. 34,712 (June 10, 2013) (to be codified at 12 C.F.R. pt. 380) (FDIC rule for Title II) with Definitions of "Predominantly Engaged In Financial Activities" and "Significant" Nonbank Financial Company and Bank Holding Company, 78 Fed. Reg. 20,756 (Apr. 5, 2013) (to be codified at 12 C.F.R. pt. 242) (Federal Reserve's rule for Title I).

8411 U.S.C. § 362; Dodd-Frank Act § 210(a)(8).

${ }^{85} 11$ U.S.C. § 1129; Dodd-Frank Act $\$ 210$ (b).

${ }^{86} 11$ U.S.C. $\$ 1129(a)(7) ;$ Dodd-Frank Act $\$ 210(d)(2)$.

${ }^{87} 11$ U.S.C. $\S \S 547-548$; Dodd-Frank Act $\S 210(\mathrm{a})(11)$.

${ }^{88} 11$ U.S.C. § 365; Dodd-Frank Act § 210(c).

${ }^{89}$ Dodd-Frank Act $\S 209$ ("To the extent possible, the [FDIC] shall seek to harmonize applicable rules and regulations promulgated under this section with the insolvency laws that would otherwise apply to a covered financial company.").
} 
available in a non-functioning market surrounding a SIFI failure. Codifying such tools allows the FDIC to ensure financial stability of the markets throughout the orderly liquidation processes.

\section{Speed of Proceedings}

Title II provides for a resolution under the OLA to be completed in an exceptionally short period of time. The statute provides for this desired speed of proceedings through provisions that limit access to the judiciary and impose severe time limits. While some of these provisions may seem novel compared to the Bankruptcy Code, they are, in fact, quite in-line with current practices that aim to conclude the reorganization process as quickly as possible.

Traditional bankruptcy law employs the judiciary to provide a forum for the balancing of power between the debtor, the creditors, the debtor-in-possession (DIP) lender, and the bankruptcy judge. The OLA, however, stifles this power struggle by the allocation of almost all power over the process in the hands of the FDIC. ${ }^{90}$ Moreover, this power is rarely subject to judicial review throughout the entirety of an orderly liquidation, ${ }^{91}$ thereby allowing the process to move along quite quickly. Although this appears at first glance to be a significant divergence from the Bankruptcy Code, that is not quite the case. In practice, current bankruptcy lawyers seek to avoid, as much as possible, the often messy and lengthy power battle through the utilization of various techniques that have been increasingly accepted by both the legislature and the judiciary. "Pre-packaged" bankruptcies cut through the battleground by allowing a DIP to use votes for a plan of reorganization obtained prior to bankruptcy to effectuate class consent. ${ }^{92}$ Section 363 sales avoid a full-fledged reorganization processes entirely by allowing a quick sale of essentially the entire bankruptcy estate, ${ }^{93}$ which, once concluded, is

\footnotetext{
${ }^{90}$ See Baird \& Morrison, supra note 1, at 288.

${ }^{91}$ Dodd-Frank Act $\S \S 202(a)(1)$ (limited judicial review of the FDIC's appointment as receiver), $210(\mathrm{~h})(17)$ (no judicial review of credit obtained for the covered financial company under $\S$ 210(h)(16)), 210(a)(9)(D), (a)(4) (limited judicial review of claims determinations).

9211 U.S.C. $\$ 1126($ b).

${ }^{93}$ Harvey R. Miller, Chapter 11 in Transition - From Boom to Bust and Into the Future, 81 AM. BANKR. L.J. 375, 385 (2007) ("Today, chapter 11 more often than not is a means to validate and sterilize the sale of a debtor's assets. This is accomplished by the use of $\S 363(\mathrm{~b})$ of the Bankruptcy Code to effect a speedy sale of all or substantially all of the debtor's assets and expedite distributions, essentially, to secured creditors.”).
} 
judicially unreviewable. ${ }^{94}$ Moreover, several other aspects of the bankruptcy process are judicially unreviewable ${ }^{95}$ which has the effect of mooting the power struggle, putting the authority to act in fewer hands, and speeding the reorganization along. Thus, the OLA appears to cut right to the result these bankruptcy techniques aim to achieve-quick, decisive action by a single entity that is not subject to judicial review. Although some question the wisdom behind the appointment of the FDIC to this position of power over financial companies with which it has little experience, ${ }^{96}$ bankruptcy judges have even less experience in such matters ${ }^{97}$ and allowing private parties to negotiate a workout without government interference would likely cause further delays and complications in the case of a SIFI failure. ${ }^{98}$ Moreover, the FDIC does have similar experience resolving failed insured depositories and has the potential to learn significantly about these nonbank financial companies through the review of the Section 165(d) Resolution Plans. So while the OLA may sacrifice some of the due process that the Bankruptcy Code (at least superficially) provides, its limited provisions for access to the judiciary are not too far removed from current practices and are arguably necessary in the case of a SIFI failure. $^{99}$

Title II time limitations also go significantly further to force a speedy OLA process. The automatic stay restricting shareholder and creditor rights ${ }^{100}$ and barring counterparty enforcement of ipso facto clauses ${ }^{101}$ lasts only for the ninety days following FDIC's appointment as receiver. Moreover, the stay against judicial proceedings involving the covered financial company also only lasts ninety days after it has been requested by the FDIC. ${ }^{102}$ The claims determination deadlines - 180 days for most claims ${ }^{103}$ and only

\footnotetext{
${ }^{94} 11$ U.S.C. $\$ 363(\mathrm{~m})$ ("The reversal or modification on appeal of an authorization...of a sale or lease of property does not affect the validity of a sale or lease under such authorization...").

${ }^{95} I d$. § 364(e) (rendering appellate review of DIP lending approval moot); U.C.C. § 9-401 (rendering grant of security in violation of negative pledge clause judicially unreviewable).

${ }_{97}^{96}$ See Scott, supra note 5, at V.A.

${ }^{97}$ See Baird \& Morrison, supra note 1, at 292 (pointing out that the bankruptcy process "calls for decisions by judges who know comparatively little about the firm or its industry).

${ }^{98} \mathrm{See} i d$. (discussing experience of private party workout to save Long-Term Capital Management, which required significant coaxing from the Federal Reserve, and pointing out that the ability of the government to step in in such a situation would be desirable).

${ }^{99}$ See Stephen J. Lubben, Some Powers for Dealing With Failed Financial Firms, N.Y. TIMES (May 10, 2011) http://dealbook.nytimes.com/2011/05/10/some-powers-for-dealing-with-failedfinancial-firms.

${ }^{100}$ Dodd-Frank Act $\S 210(a)(1)(M)$.

${ }^{101} I d . \S 210(\mathrm{c})(13)(\mathrm{C})(\mathrm{i})$.

${ }^{102} I d . \S 210(\mathrm{a})(8)(\mathrm{A})$. Note also that this is a divergence from the Bankruptcy Code in that the stay against judicial proceedings is automatic under that Code.

${ }^{103} I d . \S 210(\mathrm{a})(3)(\mathrm{A})(\mathrm{i})$.
} 
ninety days for claims requiring expedited relief ${ }^{104}$-also work to force the FDIC to act quickly. Furthermore, the FDIC has announced that it will be able to complete the receivership process and bring a covered financial company out of receivership within six to nine months using the securities-for-claims exchange method, described below. ${ }^{105}$

Although these times limits and limitations on judicial review are more stringent than those existing in the Bankruptcy Code, they reflect the industry-wide preference for quick reorganizations. Moreover, they provide the FDIC with the tools necessary to ensure a quick reorganization that would probably be much more difficult to achieve in traditional bankruptcy given the size and systemic nature of a contemplated covered financial company. $^{106}$

2. Advance Dividends and Distributions to Creditors \& Disparate Treatment of Similarly Situated Creditors

Many techniques traditionally used by bankruptcy lawyers seek to maneuver around the Bankruptcy Code's rigid absolute priority and automatic stay rules in order to favor certain "critical" or priority creditors to ensure the continued functioning of the debtor's operations. "First day motions" are typically granted by the bankruptcy judge to allow payment to such critical vendors and priority creditors under the authority of Section 363(b) of the Bankruptcy Code, which allows the trustee (or DIP), after notice and a hearing, to "use, sell, or lease other than in the ordinary course of business, property of the estate." Moreover, the use of Section 363(b) to sell essentially the entire business and, in that sale, to favor certain stakeholders over others is increasingly common and accepted by bankruptcy judges. ${ }^{107}$

${ }^{104} I d$. $\S \S 210(\mathrm{a})(5)(\mathrm{A}),(\mathrm{B})$ (expedited relief allowed to avoid "irreparable injury" to a claimant).

${ }^{105}$ SPOE Notice, supra note 58, at 76,620.

${ }^{106}$ Compare 2004 BANKRUPTCY YEARBOOK \& AlmanaC 71 (Christopher M. McHugh \& Thomas A. Sawyer eds., 2004) (in 2000, 2001, 2002, and 2003, the average length of a Chapter 11 reorganization was 14.0, 13.5, 13.8, and 18.2 months, respectively), with Michael J. De La Merced, Lehman Estate Emerges From Bankruptcy, N.Y. TIMES (Mar. 6, 2012) http://dealbook.nytimes.com/2012/03/06/lehman-estate-emerges-from-bankruptcy/ (the Lehman bankruptcy took over three years to complete).

${ }^{107}$ See e.g., In re Cont'l Airlines Corp., 790 F.2d 35 (5th Cir. 1986); In re Chrysler LLC, 405 B.R. 84 (Bankr. S.D.N.Y. 2009). 
The OLA grants to the FDIC formal authority to carry out these types of maneuvers through the ability to make advance dividends and distributions to creditors ${ }^{108}$ and to treat similarly situation creditors differently. ${ }^{109}$ While this authority may seem extremely broad at first glance, the FDIC has limited it significantly through regulations that establish which classes of stakeholders may never receive additional payments ${ }^{110}$ and provide for significant procedural requirements that must be met for any such payments to be distributed. ${ }^{111}$ Additionally, the statute itself provides several limitations upon these payments including that none may be more than the face value amount of any claim ${ }^{112}$ and that they are subject to the "no worse off than in liquidation" requirement. ${ }^{113}$ Furthermore, the FDIC has made clear that it only intends for such advance payments to be made, for example, to "essential and necessary service providers" or "creditors with contract claims that are tied to performance bonds or other creditor support needed for the covered financial company to qualify to continue other valuable contracts."114

Thus, this authority is more akin to traditional bankruptcy "first day motions" and "critical vendor" payments, than just a general carte blanche authority to abandon absolute priority as was originally feared. The aim of this authority, however, is not to simply keep the covered financial system afloat, as it is in traditional bankruptcy, but more broadly to prevent systemic collateral damage were the covered financial company

\footnotetext{
${ }^{108}$ Dodd-Frank Act $\S 210(\mathrm{~d})$ (4) (allowing the FDIC to make additional payments to certain creditors if it is determined that such payments are necessary or appropriate to minimize losses from the orderly liquidation of the covered financial company).

${ }^{109} I d . \S \S 210(\mathrm{~b})(4), 210(\mathrm{~h})(5)(\mathrm{E})$ (allowing the FDIC to treat similarly situated creditors differently pending a determination that such differential treatment is necessary (i) "to maximize the value of the assets"; (ii) "to initiate and continue operations essential to implementation of the receivership or any bridge financial company"; (iii) "to maximize the present value return from the sale or other disposition of the assets"; or (iv) "to minimize the amount of any loss realized upon the sale or other disposition of the assets").

${ }^{110}$ Orderly Liquidation Authority, 12 C.F.R. $\S \S 380.27$ (b)(1)-(3) (establishing that holders of long-term senior debt, holders of subordinated debt, and shareholders shall never receive additional payments).

${ }^{111} I d$. $\S 380.27(\mathrm{~b})(4)$ (providing that holders of short-term general unsecured debt will only receive additional payments through an affirmative vote of a majority of members of the Board of Directors of the FDIC that they are necessary and meet the requirements of Dodd-Frank Act $\S \S$ $210(\mathrm{~b})(4),(d)(4)$, and $(\mathrm{h})(5)(\mathrm{E}))$.

${ }^{112}$ Dodd-Frank Act $\S 210(\mathrm{~d})(4)(\mathrm{B})(\mathrm{i})$.

${ }^{113} I d . \S 210(\mathrm{~b})(4)(\mathrm{B})$.

${ }^{114}$ Interim Final Rule for the Orderly Liquidation Authority Provisions of the Dodd-Frank Wall Street Reform and Consumer Protection Act, 76 Fed. Reg. 4,207, 4,212 (Jan. 25, 2011) (to be codified at 12 C.F.R. Part 380) [hereinafter Interim Rule].
} 
forced to shut down systemically important operations because key vendors or creditors refused to continue doing business with it. ${ }^{115}$

\section{Orderly Liquidation Fund}

In traditional bankruptcy, debtors can obtain post-petition financing (DIP financing) to allow them to continue operations during their reorganization by granting DIP lenders seniority or security equal to or above all other pre-petition debt. ${ }^{116}$ While the OLA also authorizes similar financing, ${ }^{117}$ it further provides for a guaranteed source of liquidity from the Treasury if the FDIC cannot find anyone in the private sector to lend to the covered financial company. This government guaranteed liquidity is to come from the Orderly Liquidation Fund (OLF) and may be in the form of direct funding (senior unsecured or secured debt) or guarantees (of assets or debt issued to others). ${ }^{118}$ Immediately following the appointment of the FDIC as receiver, the maximum obligation limitation (MOL) of the OLF is $10 \%$ of the total consolidated assets of the covered financial company based upon the most recent financial statement available. ${ }^{119}$ After a preliminary valuation of the assets and preparation of a mandatory repayment plan, the MOL increases to $90 \%$ of the fair value of the total consolidated assets available for repayment. ${ }^{120}$ The OLF must be repaid either from recoveries on assets of the failed firm or from risk-based assessments imposed on eligible financial companies. ${ }^{121}$ The OLF has priority over all other claims ${ }^{122}$ and must be repaid in full before any shareholders of a covered financial company receive any payment. ${ }^{123}$

Liquidity is arguably one of the most essential aspects to the successful resolution of a SIFI. However, as was the case in the 2008 financial crisis, creditors who provide such liquidity tend to panic in the case a of a debtor failure or near failure. Financial

\footnotetext{
${ }^{115}$ See Dodd-Frank Act $§ 206$ (1) ("[In taking action under this title, the Corporation shall] determine that such action is necessary for purposes of the financial stability of the United States, and not for the purpose of preserving the covered financial company.").

${ }^{116} 11$ U.S.C. $\S \S 364(\mathrm{c})-(\mathrm{d})$.

${ }^{117}$ Dodd-Frank Act $\S \S 210(\mathrm{~h})(16)(\mathrm{B})-(\mathrm{C})$.

${ }^{118}$ Id. $\S 204(\mathrm{~d})$. But see SPOE Notice, supra note 58, at 76,617 (insisting that "[a]11 advances would be fully secured"). See also Martin J. Gruenberg, Acting Chairman, Fed. Deposit Ins. Corp., Remarks at the Fed. Reserve Bank of Chicago Bank Structure Conf. (May 10, 2012), available at http://www.fdic.gov/news/news/speeches/chairman/spmay1012.html (insisting that the FDIC's "resolution strategy will rely more on the use of guarantees than on direct funding").

${ }^{119}$ Orderly Liquidation Authority, 12 C.F.R. § 380.10(a)(1).

${ }^{120} I d$. $\$ 380.10$ (a)(2).

${ }^{121}$ Dodd-Frank Act $\S \S 214(\mathrm{~b}), 210(\mathrm{o})(\mathrm{B})$, (D).

${ }^{122}$ Id. $\S \S 204(\mathrm{~d}), 210(\mathrm{~b})(1)(\mathrm{A})-(\mathrm{B})$.

${ }^{123} I d$. $\S 206(2)$.
} 
institutions are particularly vulnerable to such panics because they rely upon short-term borrowing to continue operations. ${ }^{124}$ These short-term lenders, however, have the ability to run from a failing institution much more easily than can long-term lenders to avoid being forced to sustain a loss in a future resolution. ${ }^{125}$ Moreover, it will likely be exceptionally difficult to find a traditional DIP lender for a SIFI given its size, risk profile, and complexity. ${ }^{126}$ Thus, the OLF provides a necessary backstop to prevent such credit runs from destroying an otherwise viable reorganization by guaranteeing a SIFI access to liquidity. ${ }^{127}$

\section{Qualified Financial Contract Treatment}

In traditional bankruptcy, derivatives, repos, and other "qualified financial contracts" (QFCs) are exempt from the automatic stay, ${ }^{128}$ the stay of setoff rights, ${ }^{129}$ the trustee's contract assumption and rejection powers, ${ }^{130}$ the nullification of ipso facto clauses, ${ }^{131}$ and the trustee's avoidance powers. ${ }^{132}$ The OLA includes similar "safe-harbors" for QFCs. ${ }^{133}$ However, the OLA does provide a short window for the nullification of ipso facto clauses of QFCs until 5:00 p.m. on the business day following the appointment of the FDIC as receiver. ${ }^{134}$ This short time frame is meant to allow the FDIC to transfer a portfolio of QFCs from the failed covered financial company to a solvent counterparty, such that, ideally, upon the window's expiration, the ipso facto clause is no longer activated and can no longer be used to terminate the contract. ${ }^{135}$ According to the FDIC, "[ $\left.\mathrm{t}\right]$ he exemption from the automatic stay under the Bankruptcy Code in the case of qualified financial

\footnotetext{
${ }^{124}$ SCOTT, supra note 75 , at 107.

${ }^{125}$ See generally Mark J. Roe, The Derivatives Market's Payment Priorities as Financial Crisis Accelerator, 63 STAN. L. REV. 539 (2011).

${ }^{126}$ Hoenig, supra note 19 ("At the moment of panic, private sector lenders would be unable to determine the availability or reliability of the collateral necessary to secure massive amounts of short-term borrowed funds. Thus, even in bankruptcy, the only source of liquidity for these firms would be the government.").

${ }^{127}$ Cf. Jackson, supra note 76, at III.C. (even the proposed Chapter 14 alternative the OLA includes a provision for government-provided DIP lending, recognizing that in the case of a SIFI failure, traditional DIP lending simply will not suffice).

${ }^{128} 11$ U.S.C. $\S \S 362(\mathrm{~b})(17),(\mathrm{b})(27), 555-56,559-61$.

${ }^{129} I d . \S \S 362(\mathrm{~b})(6)-(7), 560-61$.

${ }^{130}$ Id. $\S \S 555-56,559-61$.

${ }^{131} I d$. $\S \S 555-56,559-61$.

${ }^{132} I d . \S \S 546(\mathrm{e})-(\mathrm{g}),(\mathrm{j})$.

${ }^{133}$ Dodd-Frank Act $\S \S 210(\mathrm{c})(8)(\mathrm{A}),(\mathrm{C}), 210(\mathrm{c})(11)$.

${ }^{134} I d . \S 210(\mathrm{c})(10)(\mathrm{B})$.

${ }^{135}$ Id. $\S 210(\mathrm{c})(10)(\mathrm{C})$ (for purposes of QFCs, "a bridge financial company is not considered to be a financial institution for which a conservator, receiver, trustee in bankruptcy, or other legal custodian has been appointed, or which is otherwise the subject of a bankruptcy or insolvency proceeding").
} 
contracts generally works well in most cases. However, for [SIFIs], in which the sudden termination and netting of a derivatives portfolio could have an adverse impact on U.S. financial stability, the nullification of the ipso facto clause is needed." ${ }^{136}$ Indeed, QFCs caused such disruption in Lehman's bankruptcy that a "key driver of the new regime was the need for a better mechanism to handle these contracts" in the case of a SIFI failure. ${ }^{137}$ So while there is a very clear divergence from the Bankruptcy Code in this facet of the OLA, it is a necessary one.

The OLA further seeks to minimize the risk of contractual defaults occurring during a SIFI's failure by limiting the ability of cross-default provisions to trigger a domino effect of defaults through the company's subsidiaries. Cross-default provisions "allow a nondefaulting party to terminate a contract if an affiliate of its counterparty defaults or fails." ${ }^{138}$ Because of the potential systemic consequences of these provisions, Title II vests the FDIC with the authority to enforce contracts of the subsidiaries or affiliates of the covered financial company, notwithstanding any cross-default provisions, ${ }^{139}$ such that they remain in full force and effect and may not be terminated merely as a result of the receivership process. If the obligations under such contracts are supported by the covered financial company, the support and all related assets and liabilities must be transferred either to a bridge financial company or a qualified transferee by 5:00 p.m. on the following business day, or the FDIC must provide adequate protection to the counterparties to such contracts. ${ }^{140}$ If, however, there are is no such support provided by the covered financial company, but the contract is merely linked to it, the FDIC may enforce it without providing any adequate protection or transferring anything to the bridge financial company.

Significantly, cross-default provisions may still be in effect in foreign subsidiaries or affiliates of U.S. institutions. This may only be remedied either (1) through changes in foreign law, mutual recognition agreements, or adoption of a treaty or (2) through

\footnotetext{
${ }^{136}$ FDIC Lehman Report, supra note 75 , at 38 n.41.

${ }^{137}$ Baird \& Morrison, supra note 1, at 289.

138 Jeremiah Norton, Director, Member, Board of Directors of the Fed. Deposit Ins. Corp., Opening Statement (Dec. 10, 2013), available at http:/www.fdic.gov/about/learn/board/norton/statement12-10-2013.html [hereinafter Norton (Dec. 2013)].

${ }^{139}$ Dodd-Frank Act $\S 210(\mathrm{c})(16)$.

${ }^{140}$ Orderly Liquidation Authority, 12 C.F.R. 380.12(a)(2).
} 
contractual changes removing such cross-default provisions. ${ }^{141}$ Because there are significant deficiencies with a solution that relies upon contractual changes, diplomatic solutions involving legislative and executive action may be necessary. ${ }^{142}$

\section{Single Point of Entry Strategy \& Bridge Financial Companies}

The FDIC has announced that the preferred method of resolution under the OLA will involve an approach known as the Single Point of Entry (SPOE) strategy. ${ }^{143}$ Under this strategy, only the parent holding company of the failed or failing SIFI will be placed into FDIC receivership, with all other operating subsidiaries maintaining uninterrupted operations. Key assets and associated liabilities of the parent will be transferred to a bridge financial company, with most other unsecured liabilities to be left behind in the receivership. Lastly, a securities-for-claims transaction will be completed to capitalize the new entity and resolve all old liabilities. Although this approach is significantly supported by several provisions in Title II, it is not entirely exclusive to Title II and, to a great extent, builds off of traditional bankruptcy techniques.

Specifically, the provision in Title II allowing for the creation of a bridge financial company - a temporary financial institution owned and indirectly managed by the FDIC - is a mechanism to simplify and streamline various bankruptcy maneuvers used to separate and keep good assets and liabilities and reject bad ones, such as the traditional trustee contract rejection and assumption powers in bankruptcy. ${ }^{144}$ Unlike the trustee's contracting authority in bankruptcy, however, which is subject to the court's approval, ${ }^{145}$ the FDIC, as receiver, has essentially unlimited discretion to select those assets and liabilities that will be transferred to the bridge financial company. ${ }^{146}$ Moreover, the process is even further streamlined through the proposed SPOE strategy due to the typical structure of U.S. holding companies, which have a very limited set of stakeholders and

${ }^{141}$ See Letter from FDIC, Bank of England, German Federal Financial Supervisory Authority, \& Swiss Financial Market Supervisory Authority to ISDA (requesting that the ISDA include a shortterm stay of early termination rights triggered by cross-default provisions in the standard ISDA documentation).

${ }^{142}$ Norton (Dec. 2013), supra note 138 (noting that "the practice of negotiating individual contracts occurs bilaterally between counterparties" and thus, counterparties will likely simply just not use the standard ISDA contract if it incorporates such changes).

${ }^{143}$ SPOE Notice, supra note 58.

${ }^{144}$ Compare Dodd-Frank Act $\S 210(\mathrm{~h})(5)$ (setting out FDIC's authority to transfer assets and liabilities to bridge financial company) with 11 U.S.C. $\S 365$ (trustee contract rejection and assumption powers).

${ }_{145}^{11} 11$ U.S.C. $\S 365(a)$.

${ }^{146}$ Dodd-Frank Act $\$ 210(\mathrm{a})(\mathrm{G})(\mathrm{i})(\mathrm{II})$. 
far simpler assets than do their operating subsidiaries. For the most part, nearly all assets of the holding company-primarily investments in and loans to subsidiaries-would be transferred to the bridge financial company. ${ }^{147}$ On the other hand, only those claims necessary to facilitate its operation and to mitigate systemic risk would be transferred, such as "obligations of vendors providing essential services"148 and "secured claims with the related collateral [which] would not diminish the net value of the assets in the receivership and would avoid any systemic risk effects from the immediate liquidation of the collateral." ${ }^{149}$ Just as contracts assumed in bankruptcy are given administrative priority, "liabilities transferred to the bridge financial company [in the OLA] as an ongoing institution would be paid in the ordinary course of business."

A securities-for-claims exchange would then be undertaken both to satisfy the remaining unsecured claims left in the receivership and to capitalize the new holding company such that the company is able to exit the bridge resolution stage. ${ }^{151}$ In this transaction, the claims of creditors left in the receivership would be satisfied based upon priority by an issuance of securities representing debt, equity, and, contingent securities — such as warrants or options - of the new holding company (NewCo). ${ }^{152}$ To the extent that the value of the shareholders' and remaining unsecured creditors' claims on the covered financial company exceed the value of NewCo, those claims will be written off, or "bailed-in," according to priority.

This type of exchange would provide value to the creditors without resorting to a liquidation of the assets, which would likely cause fire sales capturing little value. Moreover, the issuance of contingent value rights - such as warrants or options allowing the purchase of equity in NewCo or other instruments - to subordinated claimants, who would otherwise be impaired, protects those classes against the possibility that the approved valuation point underestimates the market value of the company." 153 Shareholders of the holding company, however, will almost certainly be entirely wiped

\footnotetext{
${ }^{147}$ SPOE Notice, supra note 58 , at 76,616.

${ }^{148} I d$. at 76,618 .

${ }^{149} \mathrm{Id}$

${ }^{150} \mathrm{Id}$

${ }^{151}$ Despite the FDIC's initial release of a hypothetical resolution of Lehman Brothers Holdings Inc. under the OLA, which contemplated a purchase and assumption of the failed company, the agency has since announced that the securities-for-claims approach is its preferred strategy. See FDIC Lehman Report, supra note 75; SPOE Notice, supra note 58.

152 SPOE Notice, supra note 58 , at 76,618.

${ }^{153} I d$. at 76,619 .
} 
out to absorb the losses of the covered financial company. This use of bail-in of shareholders and unsecured debt holders is in-line with traditional bankruptcy practice and is preferable to alternatives. ${ }^{154}$

Although questions have been raised regarding the FDIC's ability to accurately valuate these NewCos, the securities-for-claims exchange approach is still preferable to a purchase and assumption transaction or a merger ${ }^{155}$ because it would "not create additional concentration in the marketplace that otherwise would result from selling the bridge holding company to another large financial company.” Additionally, the FDIC has relayed its intention to retain independent experts, including investment bankers and accountants, to complete an accurate valuation; and the use of contingent securities, described above, should adequately protect against undervaluation. Moreover, although there is an increasingly supported argument for market sale based valuations in traditional bankruptcy due to the perceived lack of judicial expertise in valuation, such arguments likely lose much of their validity in the case of SIFIs because of their size, complexity, and the limited number of potential buyers in the market.

In order for the SPOE strategy to be effective, it is necessary that there be sufficient loss-absorbing capacity—shareholders and unsecured debt—at the holding-company level. Currently, in the U.S., "the capital structures of large financial holding companies are characterized by equity and large amounts of unsecured debt of various maturities. This debt is structurally subordinated within the group, and limited external unsecured debt tends to be raised at entities below the financial holding company." ${ }^{, 156}$ So, while this norm makes the SPOE strategy theoretically possible for U.S. SIFIs (putting aside the problem of G-SIFIs based abroad), it also "creates incentives for these companies to shift their structure." 157 Thus, the Federal Reserve has announced that it will issue a proposal to require SIFIs to hold minimum amounts of long-term, unsecured debt at the holding company level. ${ }^{158}$ Moreover, to ensure that a failed subsidiary may be effectively recapitalized through the SPOE strategy as well, there may be, included in the proposed

\footnotetext{
${ }^{154}$ Jan. 2012 SRAC Meeting, supra note 12, at 32.

${ }^{155}$ Although, these strategies for exiting the receivership are also authorized by Title II. DoddFrank Act $\S 210(\mathrm{~h})(13)$.

${ }^{156}$ FED. DEPOSIT INS. CORP. \& BANK OF ENG., supra note 48, at 13.

${ }^{157}$ Dec. 2012 SRAC Meeting, supra note 6, at 51.

${ }^{158}$ Daniel K. Tarullo, Governor, Board of Governors of the Fed. Reserve System, Speech at the Fed. Reserve 2013 Resolution Conf:: Toward Building a More Effective Resolution Regime: Progress and Challenges (Oct. 18, 2013), available at http://www.federalreserve.gov/newsevents/speech/tarullo20131018a.pdf.
} 
rule, an intracompany debt requirement. ${ }^{159}$ There remains, however, a further issue to be resolved regarding the recapitalization of the subsidiaries. As noted by some commenters to the FDIC, the current proposals address only the right side of the balance sheet (i.e., debt and capital requirements at the holding company level), but do not address the left side of the balance sheet (i.e., assets of the holding company which can actually be used to recapitalize subsidiaries). ${ }^{160}$

Finally, the FDIC has made clear that the new company would need to emerge from the receivership with a structure that corrects the problems that led to the company's failure. It must meet or exceed regulatory capital requirements, must not pose a systemic risk to the financial system, and must be resolvable under the Bankruptcy Code in the case of a subsequent failure. ${ }^{161}$ Changes necessary may include "changes in the company's business, shrinking those businesses, breaking them into smaller entities, and/or liquidating certain assets or closing certain operations." "162 Ideally, it would "result in the operations and legal entity structure of the company being more closely aligned."163 These requirements are consistent with the provision in the Bankruptcy Code that conditions approval of a plan of reorganization upon the determination that such plan "is not likely to be followed by the liquidation, or the need for further financial reorganization, of the debtor or any successor to the debtor under the plan . ..."164

Clearly, the most advantageous implication of this strategy is that key, systemically important operations at the subsidiary level may continue to function, uninterrupted by the resolution process. For example, to "the extent that operational contracts and other critical agreements are obligations of subsidiaries of the bridge financial company, they would not be affected by the appointment of the FDIC as receiver of the holding company under the SPOE strategy." 165 Moreover, because the subsidiaries "would remain open and operating as going concerns, and any obligations supporting subsidiaries' contracts would be transferred to the bridge financial company, counterparties to most of the financial company's derivative contracts would have [neither] legal right [nor

\footnotetext{
${ }^{159}$ Norton (Dec. 2013), supra note 138.

${ }^{160}$ See CCMR Comment on SPOE Notice, supra note 199.

${ }^{161}$ SPOE Notice, supra note 58, at 76,620.

${ }^{162}$ Wigand (May 2013), supra note 49. See SPOE Notice, supra note 58, at 76,620. See also SRC Comment on SPOE Notice, supra note 28, at 3 (advocating for these changes in the OLA process).

${ }^{163}$ SPOE Notice, supra note 58, at 76,220.

16411 U.S.C. $\$ 1129$ (a)(11).

${ }^{165}$ SPOE Notice, supra note 58 , at 76,622.
} 
financial motivation] to terminate and net out of their contracts." ${ }^{\text {166 }}$ Most significantly, however, is that under the SPOE, the FDIC is essentially guaranteeing the continued operation of the IDI subsidiary of the SIFI, whereas in a resolution under the Bankruptcy Code, it is very likely - and at best uncertain - that the FDIC would place the IDI subsidiary into a traditional FDIA receivership. This is so significant because for most of these SIFIs, a receivership of their IDI subsidiary means the loss of the core business, such that a true reorganization would be effectively precluded, leaving liquidation as the only possibility.

\section{Accountability \& Punitive Measures}

The FDIC has indicated that, similar to the tradition of DIP management during bankruptcy, the day-to-day management of the bridge financial company will be supervised by the officers and directors of the company, while only high-level key matters will be controlled by the FDIC. ${ }^{167}$ However, as part of the OLA's goal to eliminate moral hazard, the original management responsible for the company's failure must be removed from office and will be replaced by a new temporary board of directors and new CEO from a "pre-screened pool of eligible candidates." ${ }^{168}$ While this is a substantial deviation from the current Bankruptcy Code, it is not altogether unfamiliar from the realm of U.S. reorganizations. In fact this provision is reminiscent of the essentially mandatory displacement of management and the board of directors under Chapter X of the Chandler Act of $1938 .{ }^{169}$ And although Chapter 11 of the current Bankruptcy Code was enacted to provide more job security to managers than did the

\footnotetext{
${ }^{166} I d$. at 76,616. See also Orderly Liquidation Authority, 12 C.F.R. 380.12 (interpreting DoddFrank Act $\$ 210(\mathrm{c})(16)$ to allow the FDIC, as receiver, to enforce the contracts (including the qualified financial contracts) of subsidiaries and affiliates, notwithstanding any ipso facto clauses, for one business day so that the default clauses are never triggered if the contracts are successfully moved over to the healthy bridge financial company).

${ }^{167}$ SPOE Notice, supra note 58 , at 76,617.

${ }^{168} \mathrm{Id}$. at $76,616$.

${ }^{169}$ See Harvey J. Miller \& Shai Y. Waisman, Is Chapter 11 Bankrupt?, 47 B.C. L. REV. 129, 139 (under Chapter X, "[m]anagement and, in effect, the board of directors were displaced by the mandatory appointment of a reorganization trustee"); Chandler Act of 1938, Pub. L. No. 75-696, 52 Stat. 840, repealed by Bankruptcy Reform Act of 1978, Pub. L. 95.598, 92 Stat. 2549.
} 
Chandler $\mathrm{Act}^{170}$ and contains no mandatory management removal, it is still quite common for management to be replaced in the midst of a bankruptcy. ${ }^{171}$

The punitive measures to be taken against senior executives and directors responsible for a covered financial company's failure are also familiar to current bankruptcy law, particularly those provisions added to the Code in $2005 .{ }^{172}$ The FDIC has the authority to hold liable directors, officers, attorneys, accountants, and others for grossly negligent conduct that resulted in the "improvident or otherwise improper use or investment of any assets of the covered financial company." 173 Moreover, the FDIC also has the authority to recoup from current or former senior executives or directors substantially responsible for the failure of the company any compensation received during the two years prior to the receivership ${ }^{174}$ and the Federal Reserve has the authority to bar certain such executives from working for any financial institution for a period of time. ${ }^{175}$

\section{Assessment of PURPose}

Through the OLA provisions addressed above, both those that diverge from and those that coincide with the Bankruptcy Code, the new resolution regime created by the DoddFrank Act aims to achieve two goals which cannot be met under current traditional bankruptcy law: (1) perseveration of financial stability of the market in the case of a SIFI's failure, and (2) minimization of moral hazard. ${ }^{176}$ The first of these twin goalspreservation of financial stability in the case of a failure-is concerned directly with expost failure management. This encompasses not only the mitigation of direct collateral damage caused by significant SIFI interconnectedness, but also indirect collateral damage caused by contagion spurred by a SIFI's failure. The second goal-minimization of moral hazard-, although technically a restriction on the ex-post methods that may be used to achieve the first goal (e.g., a bar against bail-outs), is, in fact, primarily concerned with ex-ante incentive structuring to prevent failure in the first place (i.e., risk

${ }^{170}$ See Miller \& Waisman, supra note 169, at 143 (detailing the "comfort zone" provided by Chapter 11 to debtors and management).

${ }^{171}$ See id. at 155 ("during times of financial distress, there is a $52 \%$ likelihood of senior management turnover in any year in which the debtor declares bankruptcy or engages in an out-ofcourt restructuring").

${ }_{172}$ Baird \& Morrison, supra note 1, at 307-308.

${ }_{174}^{173}$ Id. (citing Dodd-Frank Act $\S 210(\mathrm{f})$, (g)).

${ }^{174}$ Dodd-Frank Act $\S 210(\mathrm{~s})(1)$; SPOE Notice, supra note 58, at 76,617.

${ }^{175}$ Dodd-Frank Act $\$ 213(\mathrm{c})(1)$.

${ }^{176}$ Dodd-Frank Act $\S 204$ (a) ("It is the purpose of this title to provide the necessary authority to liquidate failing financial companies that pose a significant risk to the financial stability of the United States in a manner that mitigates such risk and minimizes moral hazard."). 
minimization). The elimination of moral hazard, thus, also has two facets: (1) a minimization of reliance on the "Too Big To Fail" (TBFT) subsidy and (2) the maximization of market discipline. ${ }^{177}$

At the outset, these two goals do not seem to be in tension. The most plausible way to achieve both the goal of financial stability and of minimization of moral hazard is through the use of the tools available under this new resolution regime, described above, to bring certainty to the market. For example, if the financial industry is certain where losses will be borne in the case of a SIFI failure, they will cease relying upon the government to bear such losses. That is, if creditors are certain that they will bear those losses, their monitoring incentives will increase and they will be able to prevent the debtor from undertaking activities that are simply too risky (through increased finance charges, contract covenants, etc.) and market discipline will be restored, thus reducing the likelihood of initial failure. ${ }^{178}$ Furthermore, creating certainty regarding what will happen if a SIFI fails reduces the potential for panic-induced contagion when a SIFI actually does, indeed, fail.

Several specific provisions of Title II, including the prohibition of government bailouts, ${ }^{179}$ the mandate of creditor priority, ${ }^{180}$ and the FDIC's mandate to align the OLA with the Bankruptcy Code ${ }^{181}$ seek to ensure certainty of where losses will be borne if there is a failure. Moreover, as discussed above, the publicly released portions of the Title I, Section 165(d) Resolution Plans also have the potential to provide increased transparency to the market regarding specific SIFI structures and where potential losses may be borne. ${ }^{182}$

\footnotetext{
${ }^{177}$ While these facets are interrelated, I will treat them individually in this paper. Although the promotion market discipline may lead to the end of TBTF, I argue that the goal of achieving market discipline is broader than the goal of ending reliance on the government's subsidy to firms that are too big to fail.

${ }^{178}$ See generally Mark J. Roe, supra note 125 (pointing out that if certain creditors and counterparties believed they would suffer losses in the case of their debtor's bankruptcy, they would have increased monitoring incentives which could prevent the failure altogether).

${ }^{179}$ Dodd-Frank Act $\$ 206(6)$ (mandatory bar on the FDIC "tak[ing] an equity interest in or becom[ing] a shareholder of any covered financial company or any covered subsidiary").

${ }^{180} I d$. $\S \S 206(2)$, (3) (mandatory denial of shareholder payments until after all other claims and the OLF have been fully paid; mandatory priority under $\S 210$ for unsecured claims).

${ }^{181} I d$. § 209 ("To the extent possible, the [FDIC] shall seek to harmonize applicable rules and regulations promulgated under this section with the insolvency laws that would otherwise apply to a covered financial company.").

${ }^{182}$ See supra notes $28-30$ and accompanying text.
} 
The provisions for the Orderly Liquidation Fund (OLF) ${ }^{183}$ and the mechanisms that support the SPOE approach also both provide additional certainty to the market in terms of conveying transparency regarding how the FDIC will carry out a resolution using the OLA and in terms of assuring the continuity of systemically important operations throughout the resolution process. However, each of these two tools to be utilized by the FDIC to preserve financial stability may seemingly be at odds with Title II's twin goal of eliminating moral hazard and thus require further consideration.

\section{A. The Orderly Liquidation Fund \& Moral Hazard}

The OLF - one of the most significant, distinguishing features of the OLA when compared to traditional bankruptcy-likely is, indeed, necessary for maintaining financial stability both in terms of minimizing potential collateral failures due to the interconnectedness of a failed SIFI and in terms of stemming contagion spurred by the failure of a SIFI. The OLF provides not only actual necessary liquidity to keep systemically important operations functioning, but also provides assurance to the markets of that liquidity to stem possible panic and ensuing run-like behavior. ${ }^{184}$ Run-like behavior (i.e., contagion) has existed since the beginning of the existence of the banking system. ${ }^{185}$ The only effective way to prevent such runs by short-term creditors is arguably through the guarantee of liquidity by the government as the lender of last resort or the guarantee of capital injections by the government. ${ }^{186}$ Indeed, the OLF functions much like a guarantee of government-provided liquidity and has the potential to be used to indirectly inject capital into a SIFI subsidiary (as discussed below). Of considerable importance, then, is whether use of the OLF, as such a guarantee, is reconcilable with the goal of elimination of moral hazard, both in terms of ending TBTF and in terms of promoting market discipline.

\footnotetext{
${ }^{183}$ Dodd-Frank Act $\S 210(\mathrm{n})$.

${ }^{184}$ But see supra note 6 and accompanying text.

${ }^{185}$ See SCOTT, supra note 75, at 106-108.

${ }^{186}$ See id. at 226 ("The only effective way, therefore, to protect short-term creditors is through public support, in the form of lender of last resort or public guarantees."). It is also important to note though that any assurances provided by the OLF can likely only stem contagion that may occur once a SIFI is already failing, so this guarantee of liquidity may be too little too late. The OLF cannot and is not meant to replace the Federal Reserve's traditional function as lender of last resort. See Dec. 2012 SRAC Meeting, supra note 6. Title II only provides for the broader goal of avoiding initial contagion through the reduction of moral hazard.
} 


\section{The Orderly Liquidation Fund \& "Too Big To Fail"}

The question of whether this government guarantee of liquidity is reconcilable with the resolution to end TBTF turns on the definition of TBTF. The TBTF subsidy comes in at least two forms: (1) equity capital injections that prevent bankruptcy and therefore shareholder and creditor bail-in (i.e., the typical notion of a government bailout), and (2) cheaper financing due to the perceived lack of bankruptcy risk as a result of the assumption of those capital injections. ${ }^{187}$ Clearly the former of these is only realized if and when a firm actually receives a bailout. However, according to a recent study conducted by the International Monetary Fund (IMF), large U.S. banks received a funding advantage of as much as $\$ 70$ billion between 2011 and 2012. ${ }^{188}$ That is, investors demanded at least 15 basis points less from big banks than smaller ones or companies outside the banking sector because of the perception that the government would not let them fail. ${ }^{189}$ That number is even more extreme in a study by the New York Federal Reserve, which found that investors demanded 31 basis points less from big banks. ${ }^{190}$

If it is merely the cessation of equity capital injections (and subsequently the cheaper financing obtained by reliance upon them) that is sought in order to end TBTF, then the use of the OLF to stem contagion seems to pose no threat to that goal. In fact, as mentioned above, such bailouts are directly prohibited under section 206-the "Mandatory Terms and Conditions for All Orderly Liquidation Actions"- of Title II. ${ }^{191}$ Moreover, distributions from the OLF are explicitly subject to this prohibition. ${ }^{192}$ The allowable uses of the OLF funds - for liquidity purposes only — are explicitly laid out in the Dodd-Frank Act itself $^{193}$ and made clearer through notices promulgated by the FDIC. ${ }^{194}$ Moreover, according to regulators, the OLF is only to be used if absolutely necessary when no private funding is available and only for a short period of time. ${ }^{195}$

\footnotetext{
${ }^{187}$ Stephanie Armour, Size Does Matter When It Comes to Being a Bank, IMF Says, WALL ST. J., Mar. 31, 2014, available at http://online.wsj.com/news/articles/SB10001424052702304157204579473591399577348. 
Thus, it seems to be the case that the OLF not only poses no threat to the end of TBTF, but rather, by clearly defining how government money may be used in the case of a SIFI failure, it may foster bringing about its end through correcting the market presumption of bailouts. Moreover, government guarantees of liquidity, such as the Federal Reserve's traditional role as lender of last resort, are typically not critiqued under a TBTF, antibailout argument. They are merely regulatory devices used to compensate for inefficient or non-functioning markets. Thus, use of the OLF, as such a government guarantee of liquidity, in tandem with efforts to eliminate TBTF would not be inconsistent.

On the other hand, some argue that the provision for the OLF, which may only be utilized by firms under the FDIC's OLA receivership, is essentially a new manifestation of the TBTF subsidy in a third form: guaranteed liquidity in times of failure or near failure to "Systemically Important Financial Institutions." This argument gains traction in the fact that only those financial institutions that are deemed to be so large and interconnected as to be "systemically important" (a designation that, to some extent, sounds like a euphemism for "too big to fail") are granted access to this lender of last resort liquidity. Other, smaller non-bank financial institutions have no access to such government guaranteed liquidity. ${ }^{196}$ For those who view this as a de-facto subsidy for SIFIs, the OLF seems to be irreconcilable with an eradication of TBTF. ${ }^{197}$

However, others argue that this provision for access to lender of last resort liquidity is acceptable notwithstanding the fact that it is only available to SIFIs. To them, because it is not a capital injection, it is still not a TBTF subsidy. That only some institutions have access is merely a function of governmental regulatory necessity to protect financial stability. Moreover, the burden placed on said SIFIs under the new regulatory regime of the Dodd-Frank Act arguably compensates for any possibility of subsidy gained by

supra note 58, at 76,622 (OLF to "be used only for a brief transitional period, in limited amounts with the specific objective of discontinuing its use as soon as possible.”). See also id. at 76,617 ("[Private] funding would be preferred even if the associated fees and interest expenses would be greater than the costs associated with advances obtained through the OLF.").

${ }^{196}$ See SCOTT, supra note 75, at 227-228 (discussing the implications of the Dodd-Frank Act's new limitations upon the Federal Reserve's section 13(3) power to lend to non-bank financial institutions such that no individual entity may gain access; it must be made available on a market wide basis if it is to be used at all now.).

${ }^{197}$ It should be noted that an even more radical line of thought would be that all lender of last resort functions are essentially a government bailout; that is, even the Federal Reserve's traditional function. See e.g., Steven J. Lubben, Why Federal Reserve Support Is Really a Bailout, N.Y. TIMES (Dec. 19, 2013) http://dealbook.nytimes.com/2013/12/09/why-federal-reserve-support-isreally-a-bailout/. 
potential access to the OLF. For example, the very firms that supposedly would gain through this new TBTF subsidy may be carrying the brunt of the cost of such financing through risk-based assessments imposed upon them if the assets of the failed SIFI are insufficient to repay in full the obligations to the Treasury. ${ }^{198}$

Lastly, a further complication in this analysis is raised by the possibility that the OLF may, indeed, be used, not only for liquidity, but also (albeit indirectly) for capital injections at the subsidiary level. Specifically, it remains uncertain how or if the capital injection limitations will restrict a holding company's use of the OLF funds to aid in the recapitalization of its subsidiaries per the SPOE resolution approach. For example, would it violate the bar against bailouts and raise the specter of TBTF if the holding company borrows from the OLF, then lends those funds to its subsidiary, but then cancels the debt immediately? That would effectively inject capital into the subsidiary, but it would also keep the holding company on the line for the debt still owed to the Treasury. ${ }^{199}$ Does that change if the holding company actually has assets of value to borrow against such that the OLF loan remains fully secured? $?^{200}$

\section{The Orderly Liquidation Fund \& Market Discipline}

Putting aside the possibility of indirect usage of the OLF for capital injections, there is further question regarding the how the OLF's use as a government guarantee of liquidity may affect market discipline, in the broader sense, to continue the perpetuation of moral hazard. Once again such determination turns upon the definition of the goal sought. If market discipline is demanded such that no government intervention is contemplated or allowed, ${ }^{201}$ any support from the government, whether in the form of capital injections or lender of last resort liquidity under a new resolution regime, is unacceptable. In that case, the OLF, as government guaranteed liquidity, is irreconcilable with the goal of market discipline.

\footnotetext{
${ }^{198}$ Dodd-Frank Act $\S 210(0)$.

${ }^{199}$ See Comm. on Capital Mkts. Reg. Comment Letter to the Fed. Deposit Ins. Corp. Notice regarding Resolution of Systemically Important Financial Institutions: The Single Point of Entry Strategy, 78 Fed. Reg. 76614, Feb. 18, 2014 [hereinafter CCMR Comment on SPOE Notice].

${ }^{200}$ It may be the case that the holding company cannot directly transfer those assets of value to the subsidiary due to independent regulations barring the subsidiary from holding assets of that type. Thus, this sort of indirect transfer of value through the OLF would be necessary. See id.

${ }^{201}$ See Dec. 2013 SRAC Meeting, supra note 28 (Simon Johnson and Anat Admati comments).
} 
If, however, the threshold demand for market discipline is lowered and it is accepted that there will inevitably always be market volatility, and lender of last resort liquidity is indeed acceptable to compensate for such volatility to ensure the financial stability of the economy, then the OLF is acceptable. Given that such a lender of last resort mechanism for commercial banks has been traditionally accepted, it seems illogical to reject the extension of such a mechanism for all financial institutions that engage in maturity transformation.

A potential problem to be explored, however, is whether this analogy is appropriate. Is the depository banking system of the Depression-era, which prompted sustained reliance on the Federal Reserve as a lender of last resort, truly analogous to the betmaking high-risk-taking shadow banking system of today? Should institutions operating within the shadow banking system receive such government guaranteed liquidity under the same argument that granted it to the depository banking system? Does the level of risk associated with either category of entities play a role in the decision to grant that guarantee? Should it? Does the value that they add to society play a role? Should it? Is shadow banking adding the same kind of wealth creation and credit extension value to society as traditional depository banks? And further, if they are granted access to this government guaranteed liquidity through the OLA, should they also be subject to more intense regulation? Such considerations are beyond the scope of this paper, but arguably worth exploring in order to truly assess the level of government involvement in these institutions at which society is comfortable.

\section{B. Single Point of Entry \& Moral Hazard}

The mechanisms supporting the SPOE strategy, identified by the FDIC as the preferred method for effectuating a resolution under the OLA, are, like the OLF, arguably necessary for maintaining financial stability in the event of a SIFI's failure by ensuring continuity of systemically important operations at the subsidiary level. However, this approach also raises questions of moral hazard. Specifically, whether this approach safeguards creditors of SIFI subsidiaries in such a way that is inconsistent with the goal of reduction of moral hazard should be taken into consideration. 


\section{Single Point of Entry \& "Too Big To Fail"}

In a sense, the mechanisms of the SPOE strategy will shift the TBTF subsidy protecting creditors of SIFI subsidiaries from the government's shoulders to those creditors and shareholders of the SIFI holding company. Because only the creditors and shareholders of the holding company will likely be forced to bear the losses in the case of a failure, those transacting with the subsidiary get a de-facto subsidy protecting them from loss. Although this does not pose a problem for the goal of eliminating the government's role in providing this subsidy, it does create an issue familiar from the TBTF subsidy - that is, subsidiaries of SIFIs will be able to take advantage of market inefficiencies to obtain cheaper financing from creditors who will be willing to receive a lower return on transactions or investments since they will misperceive their risk levels as being lower than it truly is. ${ }^{202}$ Moreover, SIFI subsidiaries may also benefit from market inefficiencies generated by clients and counterparties who may transact more readily with them based on a perception of stability safeguarded by "governmental policy to prevent operational disruption and distress. ${ }^{, 203}$

\section{Single Point of Entry \& Market Discipline}

Moreover, this subsidy provided to SIFI subsidiary creditors could also have significant impacts upon market discipline. If creditors at the subsidiary level assume they will be protected from any potential loss by the creditors and shareholders at the holding company, their monitoring incentives are significantly discouraged. Not only is a reduction in monitoring incentives problematic in general, it would seem to be even more poignantly an issue specifically at the subsidiary level, given that this is where operations, which need to be monitored for excessive risk-taking, occur.

The counterarguments to these potential issues are twofold. The first is that because the risk will shift to the creditors at the holding company level, so too will the monitoring incentives shift to those creditors, who will in turn demand appropriately high interest rates to compensate for their increased risk. It is, however, questionable whether the market appreciates fully these shifts in risk to adequately price their financing. It is also questionable whether the creditors at the holding company level are adequately positioned to monitor all of the company's subsidiaries effectively and meaningfully. The

\footnotetext{
${ }^{202}$ Norton (Dec. 2013), supra note 138.

${ }^{203} \mathrm{Id}$.
} 
other counterargument offered in regards to this new creation of creditor subsidy and reduction of market discipline is that the risk does not transfer so completely to the holding company's creditors as to leave those at the subsidiary completely immune from bail-in risk, and thus, subsidiary creditors still have a need to consider such risk in their financing charges and monitoring functions. While those at the holding company level will indeed be the first to go, Title II provides for an expedited mechanism to incorporate a failed subsidiary into the receivership process along with the holding company if necessary, ${ }^{204}$ thereby putting the creditors of that subsidiary at risk to bear losses. ${ }^{205}$ This, however, will likely not happen unless the losses are so great that the holding company cannot bear them. It would also have the potentially extremely negative consequence of causing disruptions of systemically important operations at the operating subsidiary level, precisely what the SPOE approach seeks to avoid.

The FDIC is admittedly continuing to reach for a position regarding the SPOE approach that will create certainty regarding the resolution approach to be used and allow the operating subsidiaries to continue functioning to prevent systemic risk, but also ensure that market discipline is maintained at all levels of the company. Another consideration that has been offered, however, is that regardless of the negative impacts on market discipline that the proposed SPOE approach may have on creditor monitoring incentives and inefficient risk pricing in financing, the situation is still better now with the existence of this resolution regime than it was in 2008 when moral hazard was even more pervasive.

\section{Punitive and Accountability Measures \& Financial Stability}

Also worthy of consideration, are those provisions which clearly seem to promote the elimination of moral hazard, but which may have questionable effects on financial stability - the punitive and accountability measures to be taken if a firm fails. These include the mandatory removal of responsible management and board members ${ }^{206}$ and the "mandatory" liquidation of the failed company. ${ }^{207}$ Although the FDIC does seem quite serious regarding its determination to remove those responsible for the failure of the firm,

\footnotetext{
204 Dodd-Frank Act $\S 210(\mathrm{a})(1)(\mathrm{E})$.

${ }^{205}$ Wigand (May 2013), supra note 49.

${ }^{206}$ Dodd-Frank Act $\S \S 206(4)$, (5) (mandatory removal of management and members of the board of directors "responsible for the failed condition of the covered financial company").

${ }^{207} I d$. § 214(a) ("All financial companies put into receivership under this title shall be liquidated.").
} 
it is unclear precisely how this will be implemented in practice in a way that does not cause financial instability. For example, if the holding company is the only company put into receivership in order to effectuate the SPOE approach, but the "responsible management" is at the operating subsidiary level, who will be removed? ${ }^{208}$ Moreover, how the FDIC will determine the sufficient level of responsibility is, as of yet, also unclear. It may, indeed, be quite difficult to determine whether the failure of the company is due to poor management decisions or overall, uncontrollable market conditions. ${ }^{209}$ Lastly, the FDIC has indicated there will be a "pre-screened pool of eligible [management] candidates" from which the replacements for those removed may be chosen. ${ }^{210}$ However, it has been pointed out that insider knowledge of the firm, its assets, and its interconnectedness will be extraordinarily hard to replace ${ }^{211}$ and significant value could be lost from removal of that knowledge.

The mandatory liquidation of the company - in fact the very name of the "Orderly Liquidation Authority"-also creates some confusion, if not actual uncertainty, regarding the approach to be taken to resolve a failed SIFI. Liquidation and reorganization technically indicate two different methods of resolving a failed company. Liquidation involves selling off assets and closing down the business, while reorganization involves recapitalization and a going-concern business. Although a liquidation is clearly called for in the text of the statute, a true liquidation of a SIFI would likely have significant problematic impacts on the financial stability of the market, causing fire-sales of assets, significant value loss, and contagion. Indeed, this is likely precisely why the FDIC seems to have never even considered such a true liquidation approach to its OLA implementation. ${ }^{212}$ Rather, the FDIC has emphasized use of the SPOE approach and

\footnotetext{
${ }^{208}$ See Stephen J. Lubben Comment Letter to the Fed. Deposit Ins. Corp. Notice regarding Resolution of Systemically Important Financial Institutions: The Single Point of Entry Strategy, 78 Fed. Reg. 76614, Feb. 7, 2014.

${ }^{209}$ See Jan. 2012 SRAC Meeting, supra note 12, at 34 (Member Admati noting that "it will be difficult to determine culpability in some circumstances, such as where a decision to take a risk was made by an individual and may have been a good, rational decision on their part, but had a bad outcome.").

${ }^{210}$ SPOE Notice, supra note 58 , at 76,616.

${ }^{211}$ See id. at 34 (Member Johnson noting that "there have been many instances in which the marketplace has allowed management in the financial sector to remain because of their knowledge and expertise — or the lack of available substitutes — to prevent further loss of value.").

212 See id. at 30 (then-FDIC General Council Michael Krimminger pointing out that regardless of whether the process "more closely resembles a Chapter 11 reorganization under the Bankruptcy Code or a Chapter 7 liquidation, ... in both instances, given the type of services and operations these companies provide, an immediate cessation of those activities would clearly pose systemic risk; and that, regardless of the ultimate composition or structure of the surviving entity and how
} 
securities-for-claims method of recapitalization, which seek to maintain critical services and operations of the company in a reorganization-like, rather than liquidation-like, resolution. ${ }^{213}$ Although this departure from clear statutory text may create some reason for pause, it should also be noted that the lines between liquidation and reorganization even in traditional bankruptcy have become increasingly blurred. Reorganizations may occur under the Bankruptcy Code's Chapter 7 provision for liquidation, while liquidations may occur under the Chapter 11 provision for reorganization. The importance of these distinctions has thus become less important.

\section{The Utilization of the OLA}

The most worrisome aspect of Title II in terms of the certainty it brings to or removes from the market is in the uncertainty surrounding the actual utilization of the OLA-that is, both the uncertainty regarding which firms are eligible for resolution under the OLA and the uncertainty regarding under what circumstances the OLA will, in fact, be chosen to resolve a firm instead of allowing it to go through traditional bankruptcy.

The first of these - regarding the eligibility of firms for resolution under the OLAcreates significant uncertainty because, as discussed in Part II.B.3, a company may be eligible for resolution under Title II even if it has not been designated for supervision by the Federal Reserve under Title I. ${ }^{214}$ The possibility of a firm being forced into an OLA receivership with no prior Title I preparation is unsettling to some degree and this inconsistency could and should be addressed by the FDIC and the Federal Reserve to provide further clarification.

The second aspect of this uncertainty of the actual utilization of the OLA-the triggering of the use of the OLA - creates significant uncertainty for several reasons. First is the fact that the triggering of the OLA involves multiple players - the "three keys"- and is essentially a political decision. Introducing politics creates uncertainty that depends, inter alia, on which political party is currently in control and when the next election season is. Additionally is the tension, discussed in Part II.B.2, between the FDIC's insistence that the OLA will be used only in "extraordinary circumstances" and

those assets are treated, there has to be some continuity of operations and businesses for some period of time.").

${ }^{213}$ SPOE Notice, supra note 58.

${ }^{214}$ See supra notes $79-83$ and accompanying notes. 
the general view that neither traditional bankruptcy nor private market solutions will be able to effectively handle a SIFI failure. ${ }^{215}$

Although the mandate to align the OLA with the Bankruptcy Code ${ }^{216}$ and the "no worse off than in liquidation" ${ }^{217}$ requirement may alleviate the importance of this decision to some degree, there remain key differences between the two resolution regimes that make the decision an important one. Most significantly, as discussed above are the guaranteed use of the OLF and the mechanisms that support the SPOE strategy, both of which create a distinguishable advantage to those SIFIs being resolved under the OLA over those forced to resolve themselves under the Bankruptcy Code without such protections.

In light of this, it becomes even clearer why the FDIC has been unwavering with regard to its position that the Bankruptcy Code is, indeed, preferable to resolution under the OLA. If the market truly believes that traditional bankruptcy will, in fact, be used to let a firm fail in most cases, many of the moral hazard problems discussed above will not be such an issue. There will be no guarantee of the OLF because resolution under the OLA is not guaranteed. Similarly, there will be no guarantee of subsidiary creditor protection because a resolution utilizing a SPOE approach is not guaranteed. ${ }^{218}$ Furthermore, general market discipline will resurface and the TBTF subsidy will shrink if creditors truly believe they are exposed to some degree of default risk and bail-in in that their debtor SIFIs will be subjected to the Bankruptcy Code if they do fail. However, to the extent that resolution of a SIFI under the current Bankruptcy Code is simply not a credible option for these firms without breaking them down and to the extent that any new changes to the Bankruptcy Code would not eliminate the potential moral hazard problems posed by the OLA (because they, too, involve government funding), such moral hazard as discussed above may, indeed, be unavoidable if financial stability is to be ensured.

\footnotetext{
${ }^{215}$ See supra notes $71-78$ and accompanying text.

${ }^{216}$ Dodd-Frank Act $§ 209$.

${ }^{217} I d . \S 210(\mathrm{~d})(2)$.

${ }^{218}$ However, if the FDIC and Federal Reserve do establish minimum holding company unsecured debt requirements, a SPOE approach shielding subsidiary creditors may be effectuated effectively even through a traditional bankruptcy resolution. The guarantee of this approach, however, will not be maintained.
} 


\section{CONCLUSION}

Many problems remain to be addressed by the FDIC in its continued promulgation of rules outlining the contours of this new resolution regime. In terms of its ability to ensure financial stability of the market in the case of a SIFI failure, it is questionable whether the OLA even has the ability to truly deal with contagious panics like that which occurred in 2008. Moreover, several key provisions of the OLA remain unclear such that they may foster uncertainty in the market, which could in fact spur a panic rather than contain one in the case of a near SIFI failure. It is also clear that significant work remains to be done to achieve assurances of cross-border coordination necessary during a G-SIFI resolution. It may indeed be the case that binding agreements with foreign regulators are the only way to guarantee such coordination. Additionally, the industry and public alike remain skeptical regarding the usefulness of Section 165(d) Resolution Plans and doubt regulators' willingness to utilize this planning process to preemptively force SIFI restructuring that would simplify firm organizations to prevent initial failures altogether. Moral hazard problems also continue to permeate the current OLA resolution strategy suggested by the FDIC. TBTF persists in the possible use of the OLF to indirectly inject capital into subsidiaries and market discipline remains weak due to the de-facto subsidy that the SPOE approach seems to provide for subsidiary creditors. How these issues will be resolved may only be discovered if and when the next SIFI fails and if the regulators choose to resolve it under the OLA. Until then, the dialogue between regulators, politicians, finance professionals, lawyers, and academics will continue, seeking to eke out the theoretical ideal orderly liquidation of a significantly important financial institution. 